Prepared in cooperation with the Florida Department of Agriculture and Consumer Services, and the Southwest Florida Water Management District

\title{
Sampling History and 2009-2010 Results for Pesticides and Inorganic Constituents Monitored by the Lake Wales Ridge Groundwater Network, Central Florida
}

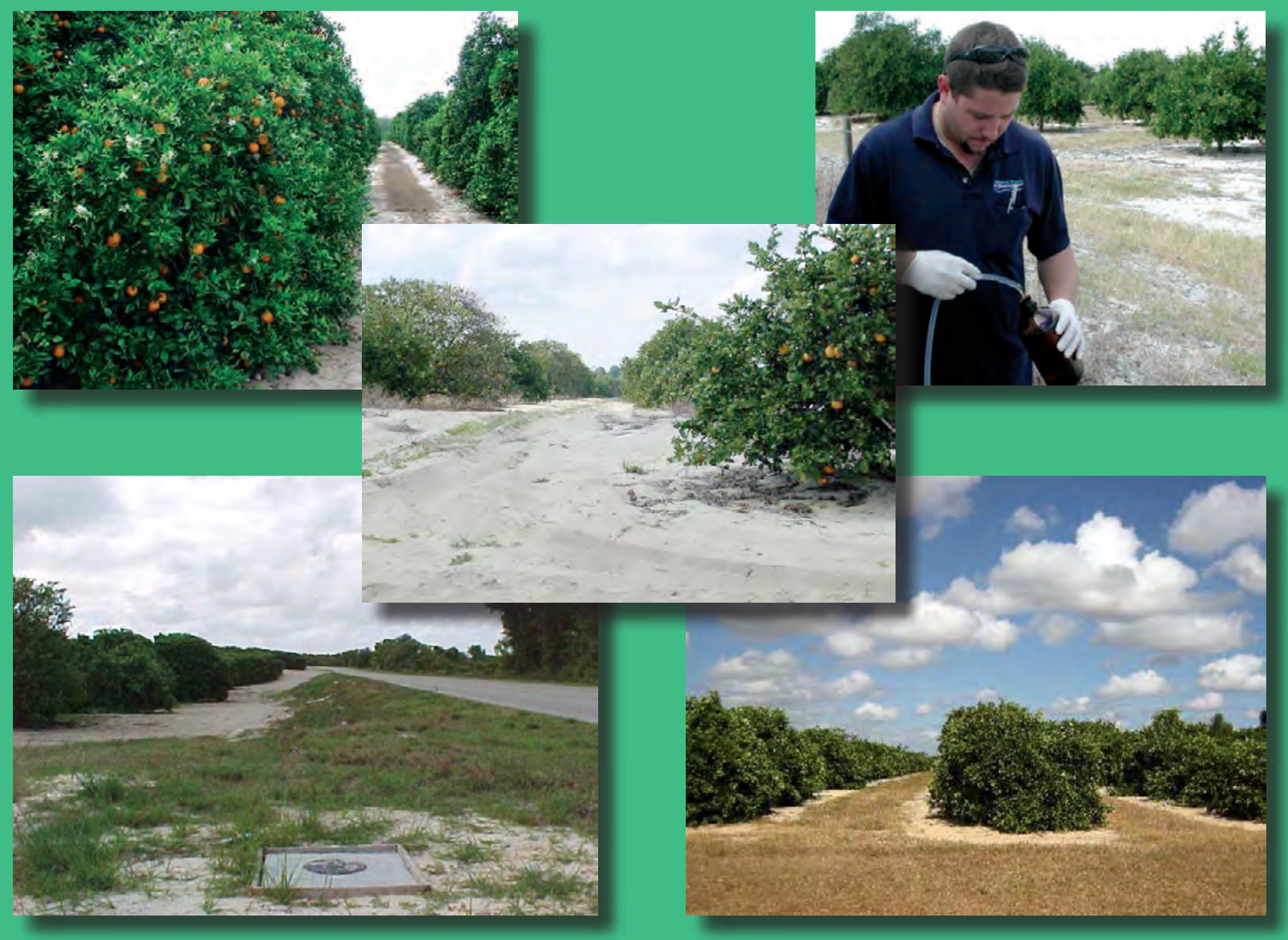

U.S. Geological Survey Open-File Report 2012-1231

U.S. Department of the Interior

U.S. Geological Survey 
Cover. Cover photographs of citrus orchards in the vicinity of Lake Wales Ridge Monitoring Network sites, courtesy of the Southwest Florida Water Management District. 


\section{Sampling History and 2009-2010 Results for Pesticides and Inorganic Constituents \\ Monitored by the Lake Wales Ridge Groundwater Network, Central Florida}

By A.F. Choquette, R. Scott Freiwald, and Carol L. Kraft

Prepared in cooperation with the Florida Department of Agriculture and

Consumer Services, and the Southwest Florida Water Management District

U.S. Geological Survey Open-File Report 2012-1231

U.S. Department of the Interior

U.S. Geological Survey 


\title{
U.S. Department of the Interior \\ KEN SALAZAR, Secretary \\ U.S. Geological Survey \\ Marcia K. McNutt, Director
}

\author{
U.S. Geological Survey, Reston, Virginia: 2012
}

For more information on the USGS - the Federal source for science about the Earth, its natural and living resources, natural hazards, and the environment, visit http://www.usgs.gov or call 1-888-ASK-USGS.

For an overview of USGS information products, including maps, imagery, and publications, visit http://www.usgs.gov/pubprod

To order this and other USGS information products, visit http://store.usgs.gov

Any use of trade, firm, or product names is for descriptive purposes only and does not imply endorsement by the U.S. Government.

Although this information product, for the most part, is in the public domain, it also may contain copyrighted materials as noted in the text. Permission to reproduce copyrighted items must be secured from the copyright owner.

Suggested citation:

Choquette, A.F., Freiwald, R.S., and Kraft, C.L., 2012, Sampling history and 2009-2010 results for pesticides and inorganic constituents monitored by the Lake Wales Ridge Groundwater Network, Central Florida: U.S. Geological Survey Open-File Report 2012-1231, 19 p. 


\section{Contents}

Abstract
Introduction
Purpose and Scope
Water Quality Benchmarks
Rainfall and Groundwater Levels
Pesticides and Selected Inorganic Agrichemical Results from the Citrus Land-Use Wells,
January 2009 through May 2010
Comparison of Results from Citrus and Non-Citrus Land-Use Wells, 2009
Pell Construction
Pesticides and Pesticide Degradates
References Cited.

\section{Figures}

1. Map showing locations of the Lake Wales Ridge Monitoring Network wells, citrus land use, and vulnerable soils in the study area ...................................................

2. Chart showing long-term annual rainfall at Archbold Biological Station,1932 through 2010

3. Charts showing $(A)$ annual rainfall departures from the long-term mean compared to $(B)$ water-levels records from two wells with shallow and deep water tables

4. Chart showing comparison between pesticide detection frequencies in samples from citrus and non-citrus land-use wells during the January and July 2009 sampling events

5. Image showing land use in the vicinity of the USGS Shallow Observation Well on US Highway 27 (site NC1) and the Ridge WRAP P4 well (site NC2), on December 2, 2010

\section{Tables}

1. Sampling history at the Lake Wales Ridge Monitoring Network wells, in Florida, 1989 through May 2010

Separate Excel file

2. Description of the Lake Wales Ridge Monitoring Network wells in Florida, including well construction, land-use classification, and depth

to water table Separate Excel file 
3. Analytes evaluated and laboratory methods performed by the Southwest Florida Water Management District Water Quality Laboratory.

4. Historical record of laboratory detection levels for pesticides and selected inorganic chemicals analyzed at the Florida Department of Agriculture and Consumer Services laboratories, April 1999 through May 2010.

Separate Excel file

5. Spike recovery results for selected pesticides and pesticide degradates analyzed in groundwater samples, January 2009 through May 2010.

6. Summary of health benchmarks and agrichemical usage information for selected organic and inorganic chemicals detected in groundwater samples from Lake Wales Ridge Monitoring Network wells

Separate Excel file

7. Years and months during 1999-2009 when rainfall totals exceeded 10 inches at Archbold Biological Station near Venus, Florida.

8. Analyzed pesticides and pesticide degradates that were not detected in samples from citrus land-use wells, January 2009 through May 2010, and laboratory detection levels during this period.

9. Summary of pesticide, copper, arsenic, and nitrate detections in groundwater samples from citrus land-use wells, January 2009 through May 2010.....

10. Summary of well construction and sampling depths at wells sampled in the land-use comparison

11. Comparison of physical properties, nutrients, and inorganic constituent concentrations between groundwater samples from citrus and non-citrus land-use wells

12. Comparison between detections and concentrations of pesticides, copper, arsenic, and nitrate in groundwater samples from citrus and non-citrus land-use wells 


\section{Conversion Factors}

\begin{tabular}{|c|c|c|}
\hline Multiply & By & To obtain \\
\hline \multicolumn{3}{|c|}{ Length } \\
\hline inch (in.) & 2.54 & centimeter $(\mathrm{cm})$ \\
\hline foot $(\mathrm{ft})$ & 0.3048 & meter $(\mathrm{m})$ \\
\hline mile (mi) & 1.609 & kilometer (km) \\
\hline \multicolumn{3}{|c|}{ Area } \\
\hline square mile $\left(\mathrm{mi}^{2}\right)$ & 2.590 & square kilometer $\left(\mathrm{km}^{2}\right)$ \\
\hline \multicolumn{3}{|l|}{ SI to Inch/Pound } \\
\hline Multiply & By & To obtain \\
\hline \multicolumn{3}{|c|}{ Length } \\
\hline micrometer $(\mu \mathrm{m})$ & $3.937008 \mathrm{E}-5$ & inch (in) \\
\hline \multicolumn{3}{|c|}{ Volume } \\
\hline liter $(\mathrm{L})$ & 33.82 & ounce, fluid (fl. oz) \\
\hline liter $(\mathrm{L})$ & 0.2642 & gallon (gal) \\
\hline \multicolumn{3}{|c|}{ Mass } \\
\hline milligram (mg) & $3.527396 \mathrm{E}-5$ & ounce, avoirdupois (oz.) \\
\hline microgram $(\mu \mathrm{g})$ & $3.527396 \mathrm{E}-8$ & ounce, avoirdupois (oz) \\
\hline
\end{tabular}

Temperature in degrees Celsius $\left({ }^{\circ} \mathrm{C}\right)$ may be converted to degrees Fahrenheit $\left({ }^{\circ} \mathrm{F}\right)$ as follows:

${ }^{\circ} \mathrm{F}=\left(1.8 x^{\circ} \mathrm{C}\right)+32$

Vertical coordinate information is referenced to the North American Vertical Datum of 1988 (NAVD 88).

Horizontal coordinate information is referenced to the North American Datum of 1983 (NAD 83).

Altitude, as used in this report, refers to distance above the vertical datum.

Specific conductance is given in microsiemens per centimeter at 25 degrees Celsius $(\mu \mathrm{S} / \mathrm{cm}$ at $\left.25^{\circ} \mathrm{C}\right)$.

Concentrations of chemical constituents in water are given either in milligrams per liter (mg/L) or micrograms per liter $(\mu \mathrm{g} / \mathrm{L})$. 


\section{Abbreviations and acronyms}

\begin{tabular}{|c|c|}
\hline$<$ & Less than \\
\hline$>$ & Greater than \\
\hline DEA & deethylatrazine, or 2-chloro-4-isopropylamino-6-amino-s-triazine (CIAT) \\
\hline DIA & deisopropylatrazine, or chloro-6-ethylamino-4-amino-s-triazine (CEAT) \\
\hline FDACS & Florida Department of Agriculture and Consumer Services \\
\hline FDEP & Florida Department of Environmental Protection \\
\hline GC & Guidance concentration \\
\hline HA & Health advisory \\
\hline HAL & Lifetime health advisory levels \\
\hline HBSL & Health-based screening level \\
\hline HPLC & High-performance liquid chromatography \\
\hline LC/MS & Liquid chromatography/mass spectroscopy \\
\hline LWRM & Lake Wales Ridge Monitoring \\
\hline MCL & Maximum contaminant level \\
\hline MCPP & Mecoprop; or 2-(4-chloro-2-methyl phenoxy) propionic acid \\
\hline MDL & Method detection level \\
\hline$\mu \mathrm{g} / \mathrm{L}$ & microgram per liter \\
\hline$\mu \mathrm{S} / \mathrm{cm}$ & microsiemens per centimeter \\
\hline $\mathrm{mg} / \mathrm{L}$ & milligram per liter \\
\hline $\mathrm{N}$ & Nitrogen \\
\hline NTU & Nephelometric turbidity units \\
\hline NPD & Nitrogen phosphorus detector \\
\hline$P$ & phosphorus \\
\hline Pt-Co & platinum-cobalt unit \\
\hline PTFE & Polytetrafluoroethylene (Teflon) \\
\hline POL & Practical quantitation level \\
\hline SWFWMD & Southwest Florida Water Management District \\
\hline SU & Standard units \\
\hline USEPA & U.S. Environmental Protection Agency \\
\hline USGS & U.S. Geological Survey \\
\hline VISA & Very Intensive Study Area \\
\hline
\end{tabular}




\section{Acknowledgments}

This report and the successful implementation of the 1999 through 2010 Lake Wales Ridge Monitoring Network were made possible through partnered efforts of many individuals at the Florida Department of Agriculture and Consumer Services (FDACS), the Southwest Florida Water Management District (SWFWMD), and the U.S. Geological Survey (USGS). Dennis Howard, Davis Daiker, and Keith Parmer, with the FDACS; Eric DeHaven and Roberta Starks, with the SWFWMD; and Gary Mahon, with the USGS, provided administrative support and technical guidance. The SWFWMD field sampling staff, under the direction of Jason Hust and Christopher Tomlinson, performed sample collection and land-use photo-documentation. Laboratory analyses were conducted under the supervision of Teresa Rygiel, Patricia Lucas, and Michael Page (FDACS Pesticides Laboratory), Mark Rials (SWFWMD Water Quality Laboratory), and Stacie Hammack (FDACS Food Laboratory). The authors appreciate permission granted by a number of land-owners for access to lands in the vicinity of monitoring wells in order to conduct sampling activities. 
viii

This page intentionally left blank 


\title{
Sampling History and 2009-2010 Results for Pesticides and Inorganic Constituents Monitored by the Lake Wales Ridge Groundwater Network, Central Florida
}

\author{
By A.F. Choquette ${ }^{1}$, R. Scott Freiwald ${ }^{2}$ and Carol L. Kraft ${ }^{3}$
}

\section{Abstract}

The Lake Wales Ridge Monitoring (LWRM) Network was established to provide a long-term record of water quality of the surficial aquifer in one of the principal citrus-production areas of Florida. This region is underlain by sandy soils that contain minimal organic matter and are highly vulnerable to leaching of chemicals into the subsurface. This report documents the 1989 through May 2010 sampling history of the LWRM Network and summarizes monitoring results for 38 Network wells that were sampled during the period January 2009 through May 2010. During 1989 through May 2010, the Network's citrus land-use wells were sampled intermittently to 1999, quarterly from April 1999 to October 2009, and thereafter quarterly to semiannually.

The water-quality summaries in this report focus on the period January 2009 through May 2010, during which the Network's citrus land-use wells were sampled six times and the non-citrus land-use wells were sampled two times. Within the citrus land-use wells sampled, a total of 13 pesticide compounds ( 8 parent pesticides and 5 degradates) were detected of the 37 pesticide compounds analyzed during this period. The most frequently detected compounds included demethyl norflurazon ( 83 percent of wells), norflurazon (79 percent), aldicarb sulfoxide (41 percent), aldicarb sulfone (38 percent), imidacloprid (38 percent), and diuron (28 percent). Agrichemical concentrations in samples from the citrus land-use wells during the 2009 through May 2010 period exceeded Federal drinking-water standards (maximum contaminant levels, MCLs) in 1.5 to 24 percent of samples for aldicarb and its degradates (sulfone and sulfoxide), and in 68 percent of the samples for nitrate. Florida statutes restrict the distance of aldicarb applications to drinking-water wells; however, these statutes do not

\footnotetext{
${ }^{1}$ U.S. Geological Survey, Tallahassee, Florida

${ }^{2}$ Florida Department of Agriculture and Consumer Services, Tallahassee, Florida
}

${ }^{3}$ Southwest Florida Water Management District, Tampa, Florida apply to monitoring wells. Health-screening benchmark levels that identify unregulated chemicals of potential concern were exceeded for norflurazon and diuron in 29 and 7 percent, respectively, of the 2009-2010 samples.

A comparison of agrichemical land-use effects on groundwater quality, determined on the basis of samples from LWRM Network wells in citrus and in non-citrus land-use areas, indicated significantly higher $(\mathrm{p}<0.05)$ concentrations of inorganic constituents in samples from citrus land-use areas compared to samples from non-citrus areas. These inorganic constituents include calcium, magnesium, chloride, sulfate, potassium, nitrate, aluminum, manganese, strontium, and total nitrogen, and also specific conductance, an indicator of total dissolved solutes in water. In addition to land use, including irrigation, site differences such as soils and groundwater reduction/oxidation conditions might have contributed to the differences in some of these constituents. Pesticide detections were primarily restricted to the citrus land-use wells, where 22 of 23 wells yielded pesticide detections, with a median of four detected pesticide compounds per well. For the non-citrus land-use wells, typically surrounded by mixed land use including developed and undeveloped land, one of the eight sampled wells yielded pesticide detections consisting of norflurazon and its degradate, and the source(s) of these detections might have been active or recently active citrus orchards in the vicinity of this well.

Results from the LWRM Network during the 1989 through May 2010 period have provided early warning of chemicals prone to leaching, guidance for developing or modifying chemical usage practices to minimize impacts to groundwater, and a mechanism for prioritizing State sampling of domestic wells to assure safe drinking-water supplies. Given the typically long time period (years to tens of years or longer) required to remove chemical contamination once it enters the groundwater system, groundwater monitoring is important to protect drinking-water sources as well as the numerous lakes in this region, which are closely connected with the surficial aquifer. Long-term monitoring of the LWRM Network is planned to continue providing early warning of potential for groundwater contamination, and to assess spatial and temporal trends in water quality resulting from changes in pesticide-use patterns and in land use. 


\section{Introduction}

The Lake Wales Ridge Monitoring Network, hereafter referred to as LWRM Network in this report, is located in a 700 -square mile $\left(\mathrm{mi}^{2}\right)$ upland citrus-growing area of central Florida, commonly referred to as "ridge citrus." The LWRM Network was established to provide early warning of the occurrence of pesticides in the unconfined surficial aquifer, and to evaluate the spatial and temporal variability of groundwater quality, including agrichemicals and major water chemistry (Choquette and Sepulveda, 2000; Choquette and others, 2005). The Lake Wales Ridge, hereafter referred to as the Ridge, is one of the most extensively cultivated and productive citrus areas in Florida and the Nation. Citrus is one of the top agricultural crops in Florida, in terms of both acreage and revenue, and Florida provides about two-thirds of the Nation's citrus production (Florida Agricultural Statistics Service, 2011). The study area (fig. 1) is located in Polk and Highlands Counties, Florida, which ranked first and second statewide, respectively, in total annual citrus production for the September 2009 through August 2010 crop year (Florida Agricultural Statistics Service, 2011). Citrus land use covers about 24 percent $(107,500$ acres) of the study area.

The LWRM Network represents one of the most intensively sampled regional-scale groundwater networks for seasonal and temporal variability in pesticides nationally. Due to a combination of soil type, geology, agricultural practices, and climate, the Ridge is particularly susceptible to leaching of agrichemicals into the subsurface (Wilson and others, 2002). Concentrations of nitrate and some of the detected pesticides in the groundwater underlying the Ridge have been among the highest observed among national groundwater sampling by the U.S. Geological Survey (USGS; Choquette and others, 2003). The Ridge lakes are closely connected with the surficial aquifer in this region. Samples from selected Ridge lakes (fig. 1) yielded concentrations of some pesticides that were among the highest observed in USGS national pesticide sampling in streams (Choquette and Kroening, 2009). In statewide sampling of about 4,000 Florida drinking-water wells during the 1990s, 89 percent of the 584 wells that yielded nitrate concentrations above the U.S. Environmental Protection Agency (USEPA) drinking-water standard were located in the ridge citrus region of central Florida (Graham and Alva, 1998). In response to elevated nitrate concentrations in groundwater in the region, best-management practices for fertilizer were developed for the ridge citrus region during the late 1990s and early 2000s (State of Florida, 2002; Parsons and Boman, 2006).

Wells in the LWRM Network were first sampled for water quality in 1989. Historical water-quality records are available for 12 of the network wells that were sampled intermittently during the period 1989 to 1999 (table 1, Excel file). The data prior to April 1999 were collected as part of two Florida Department of Environmental Protection groundwater networks: (1) the Background Network, and (2) the citrus land-use VISA (Very Intensive Study Area)
Network (Ouellette and others, 1998; Silvanima and others, [n.d.]; Florida Department of Environmental Protection, 2012a, b), and as part of a regional USGS water-quality study (German, 1996). Results from the LWRM Network have been used by Federal and State regulatory agencies and pesticide manufacturers to evaluate leaching propensity of some citrus agrichemcials, to develop guidelines for minimizing leaching, and to direct sampling of domestic wells to confirm that drinking-water quality is meeting health guidelines.

During recent years, several changes have occurred in citrus agrichemical usage and in land use near some Network wells. Bromacil use was prohibited in ridge citrus areas in 1994 (State of Florida, 1994; Fishel, 2005). Aldicarb use has been restricted within Florida (State of Florida, 1997) and was recently phased out in citrus orchards nationally as of January 2012 (U.S. Environmental Protection Agency, 2010). Temporal trends in groundwater quality sampled from Network wells have been related to herbicide usage patterns of bromacil and norflurazon during the 1998 to 2005 period (Choquette and others, 2005; Gilliom and others, 2006). A major recent impact on Florida's citrus agriculture has been the onset and rapid spread of citrus greening disease (also known as "Huanglongbing" from its Asian origin) first detected in Florida in August 2005 (National Academy of Sciences, 2010). The spread of this disease, transmitted by an insect, the Asian citrus psyllid, has resulted in some major changes in pest management practices in Florida citrus orchards, including the increased use of insecticides (National Agricultural Statistics Service, 2006, 2010; Rogers and others, 2010, 2012; Rogers, 2011; Brlansky and others, 2012). In addition, land-use changes that may be indicative of a change or reduction in agrichemical usage in the vicinity of some of the LWRM Network wells have included partial or extensive removal of orchards, subsequently either left fallow, replaced with new citrus replants, or converted to residential development.

\section{Purpose and Scope}

The purpose of this report is to document the April 1999 through May 2010 operation of the LWRM Network, including well characteristics, well-sampling records, sampling protocols, laboratory methods, and to summarize recent water-quality results for the January 2009 through May 2010 (2009-2010, in this report) period. The report includes a summary of 2009-2010 water-quality results for the citrus land-use wells, most of which were sampled five to six times during this period, and a comparison of groundwater quality between non-citrus and citrus land use based on samples collected during January and July 2009. The waterquality summaries for the LWRM Network's citrus land-use wells focus on agricultural chemicals including pesticides, nitrate, copper, and arsenic. The water-quality data in the land-use comparison include physical properties, inorganic constituents (including nutrients), and pesticides. 


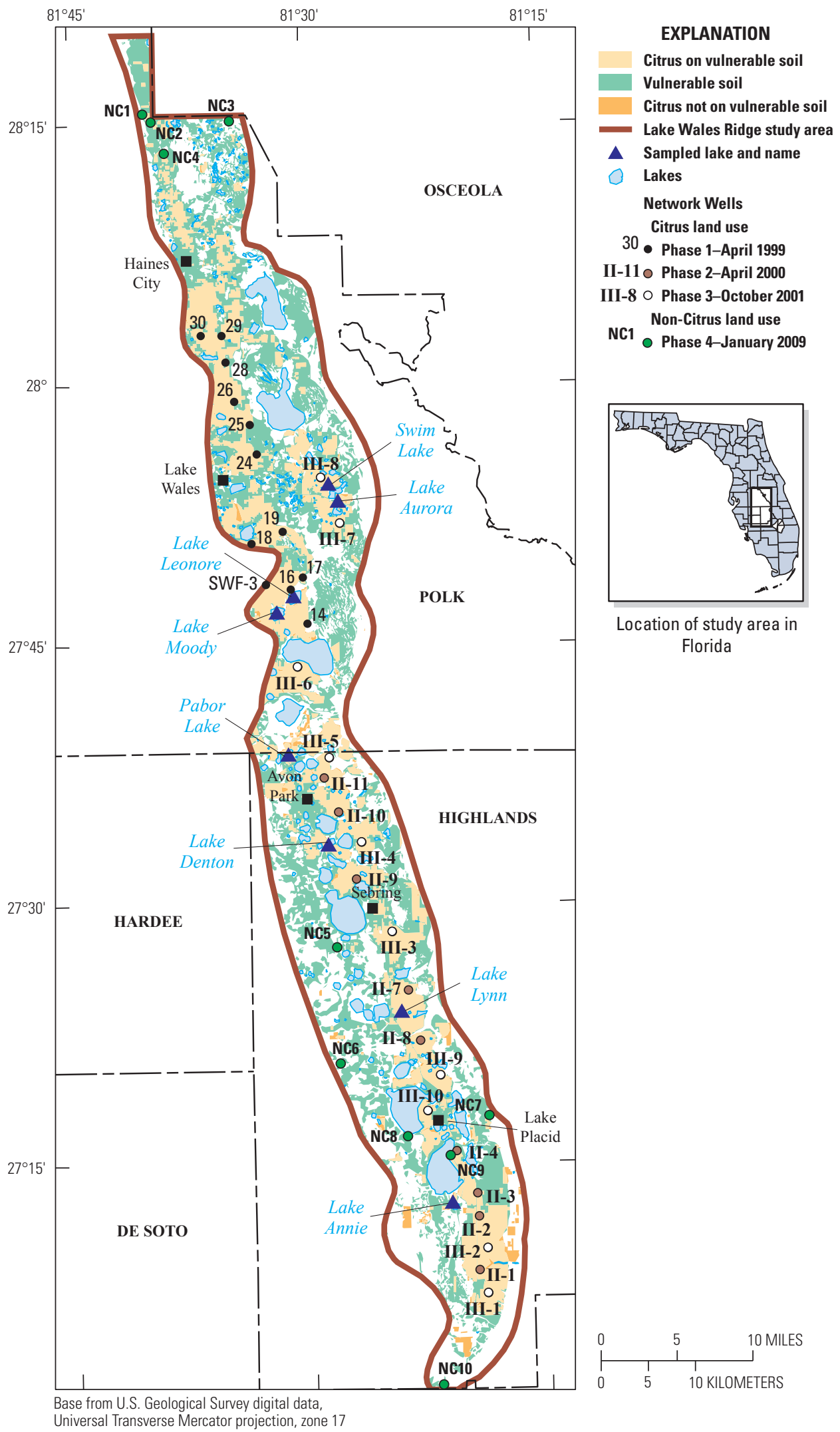

Figure 1. Locations of the Lake Wales Ridge Monitoring Network wells, citrus land use, and vulnerable soils in the study area (see Choquette and Kroening, 2009, for pesticide results from sampled lakes). 


\section{Network Design and Methods}

The LWRM Network, in May 2010, consisted of 40 wells, including 30 wells surrounded by active or, in some cases, recently discontinued citrus agriculture; and 10 wells in non-citrus land use, of which 8 have been sampled (fig. 1; tables 1, 2, Excel files). The full history of sample collection at the LWRM Network wells from 1989 through May 2010 is summarized in table 1.

Establishment of the LWRM Network occurred in phases between April 1999 and October 2001 (fig. 1, table 1) and included existing, previously sampled monitoring wells and installation of new wells (Choquette and Sepulveda, 2000). The Network's citrus land-use wells (fig. 1) were selected using a grid-based method restricted to areas of citrus land use on soils classified as vulnerable to leaching (Jackson and others, 1995; Obreza and Morgan, 2008). As of October 2001, the LWRM Network of citrus land-use wells was fully implemented and included a total of 31 citrus land-use wells sampled quarterly on an ongoing basis. Subsequently, in October 2009, the sampling frequency at 24 of the citrus land-use wells was reduced from quarterly to semiannually.

To compare potential effects of citrus agriculture on groundwater quality to non-citrus land use, 10 monitoring wells (fig. 1; table 2) in non-citrus areas were added to the LWRM Network in 2009. These wells were selected on the basis of a survey of existing surficial aquifer monitoring wells on the Ridge. Land use in the vicinity of these wells included scrub forest, rural residential and (or) commercial areas, and pasture land. During the 2009-2010 period, 8 of the non-citrus land-use wells and 23 of the citrus land-use wells were sampled twice (January 2009 and July 2009) to compare potential effects of citrus and non-citrus land use on groundwater quality.

All citrus land-use monitoring wells were drilled and developed using methods and materials according to specifications for water-quality monitoring for organic compounds (Florida Department of Agriculture and Consumer Services, 1995; Lapham and others, 1995). Well construction characteristics and approximate depths to water table are shown in table 2. At most Network wells, the screened interval is less than 10 to 20 feet (ft) below the water table. The selection of pesticides analyzed in samples from LWRM Network wells focused on pesticides used in citrus land use (Choquette and Sepulveda, 2000; Choquette and others, 2005); however, many of these pesticides also are used in urban and residential areas (Gilliom and others, 2006).

Field personnel collected and processed water samples using standardized, parts-per-billion sampling protocols (Florida Department of Environmental Protection, 2002; Southwest Florida Water Management District, 2009) and made field measurements of water-quality properties $(\mathrm{pH}$, dissolved oxygen, temperature, specific conductance) during sample collection. Field protocols included a minimum purge of three well volumes, stabilization of $\mathrm{pH}$, conductance, temperature, and dissolved oxygen prior to sample collection, and turbidity of $<10$ nephelometric turbidity units (NTU). Quality-control and quality-assurance samples represented at least 25 percent of the collected samples. Field personnel also documented land-use changes near the LWRM Network's citrus land-use wells using repeat photography in the immediate vicinity of the wells, approximately annually between October 1999 and January 2009.

Sample collection was performed by personnel from the Southwest Florida Water Management District (SWFWMD), with supplemental sampling during February 2010 performed by the Florida Department of Agriculture and Consumer Services (FDACS). All groundwater samples were analyzed for major dissolved inorganic constituents, nutrients, pesticides, and selected trace constituents at the FDACS and the SWFWMD laboratories. Analyses performed by the SWFWMD laboratory (table 3) included USEPA and standard methods (Southwest Florida Water Management District, 2011). SWFWMD field and laboratory data for the LWRM Network wells are available online at http://www18.swfwmd.state.fl.us/ResData/Search/ ExtDefault.aspx (Southwest Florida Water Management District, 2012).

Table 3. Analytes evaluated and analytical methods performed at the Southwest Florida Water Management District Water Quality Laboratory (Southwest Florida Water Management District, 2011).

[mg/L, milligram per liter; EPA, U.S. Environmental Protection Agency; $\mu \mathrm{g} / \mathrm{L}$, microgram per liter; SM, Standard Method of the Standard Method Organization; PCU, platinum cobalt units; SU, standard units; $\mu \mathrm{S} / \mathrm{cm}$, microsiemens per centimeter; NTU, nephelometric turbidity units]

\begin{tabular}{lll}
\hline \multicolumn{1}{c}{ Analyte } & Units & \multicolumn{1}{c}{ Analytical method } \\
\hline Alkalinity (total) & $\mathrm{mg} / \mathrm{L}$ & EPA 310.1 \\
Aluminum (dissolved) & $\mu \mathrm{g} / \mathrm{L}$ & EPA 200.7 (Al) \\
Ammonia (as N) (dissolved) & $\mathrm{mg} / \mathrm{L}$ & SM18 4500-NH3 H No \\
& & Distillation \\
Calcium (dissolved) & $\mathrm{mg} / \mathrm{L}$ & EPA 200.7 (Ca) \\
Carbon-total organic (total) & $\mathrm{mg} / \mathrm{L}$ & SM18 5310 B \\
Chloride (dissolved) & $\mathrm{mg} / \mathrm{L}$ & EPA 300.0 (Chloride) \\
Color (dissolved) & $\mathrm{PCU}$ & $\mathrm{SM18} \mathrm{2120} \mathrm{B}$ \\
Fluoride (dissolved) & $\mathrm{mg} / \mathrm{L}$ & SM18 4500-F C \\
Iron (dissolved) & $\mu \mathrm{g} / \mathrm{L}$ & EPA 200.7 (Fe) \\
Magnesium (dissolved) & $\mathrm{mg} / \mathrm{L}$ & EPA 200.7 (Mg) \\
Manganese (dissolved) & $\mu \mathrm{g} / \mathrm{L}$ & EPA 200.7 (Mn) \\
Nitrate-nitrite (as N) & $\mathrm{mg} / \mathrm{L}$ & EPA 353.2 (Nitrate-Nitrite (N)) \\
$\quad$ & & \\
(dissolved) & $\mathrm{mg} / \mathrm{L}$ & EPA 353.2 (Nitrite (N)) \\
Nitrite (as N) (dissolved) & $\mathrm{mg} / \mathrm{L}$ & ASTM D5176 \\
Nitrogen-total (dissolved) & $\mathrm{mg} / \mathrm{L}$ & SM18 4500-P F (Orthophos- \\
Orthophosphate (P) & & \multicolumn{1}{c}{ phate) } \\
$\quad$ (dissolved) & $\mathrm{SU}$ & SM18 4500-H B \\
pH, lab & $\mathrm{mg} / \mathrm{L}$ & EPA 365.1 (Phosphorus -Total) \\
Phosphorus-total (dissolved) & $\mathrm{mg} / \mathrm{L}$ & EPA 200.7 (K) \\
Potassium (dissolved) & $\mathrm{mg} / \mathrm{L}$ & SM18 4500-Si E \\
Silica (dissolved) & $\mathrm{mg} / \mathrm{L}$ & EPA 200.7 (Na) \\
Sodium (dissolved) & $\mu \mathrm{S} / \mathrm{cm}$ & SM18 2510 B \\
Specific conductance, lab & $\mathrm{mg} / \mathrm{L}$ & EPA 200.7 (Sr) \\
Strontium (dissolved) & $\mathrm{mg} / \mathrm{L}$ & EPA 300.0 (Sulfate) \\
Sulfate (dissolved) & $\mathrm{mg} / \mathrm{L}$ & SM18 4500-S D \\
Sulfide (total) & $\mathrm{NTU}$ & SM18 2130 B \\
Turbidity, lab & &
\end{tabular}


Pesticides and pesticide degradates were analyzed at the FDACS Pesticide Laboratory using gas chromatography with a nitrogen phosphorous detector (NPD), high-performance liquid chromatography (HPLC) (both ultraviolet/visible range and post-column derivatization), liquid chromatography/mass spectroscopy (LC/MS) and ion chromatography, and included both standard USEPA methods and FDACS custom methods for selected compounds (Rygiel, 2001, 2003; Brock and Rygiel, 2003; Page and Stepp, 2003). Pesticide samples analyzed for carbamates (aldicarb, aldicarb sulfoxone, aldicarb sulfoxide, methomyl, and oxamyl) were filtered in the laboratory using a 0.45 -micrometer $(\mu \mathrm{m})$ hydrophilic polytetrafluoroethylene (PTFE, or "Teflon") syringe filter (Teresa Rygiel, Florida Department of Agriculture and Consumer Services, written commun., Februrary 24, 2009). Copper and arsenic were analyzed at the FDACS Food Laboratory using a modification of USEPA Method 200.8, in which germanium was used as the alternate internal standard in place of the standard yttrium specified for this method, because yttrium is known to be consistently present in samples from at least one of the Ridge monitoring wells (Stacie Hammack, Florida Department of Agriculture and Consumer Services, written commun., March 3, 2012).

The 1999-2010 record of pesticide compounds and inorganic agrichemicals analyzed at the FDACS Pesticide and Food Laboratories and the associated laboratory detection levels are shown in table 4 (Excel file), including method detection levels (MDL) and practical quantitation levels (PQL). The MDL represents the level above which the presence of the compound is confirmed with 99 percent confidence. The PQL, typically three times the value of the $\mathrm{MDL}$, is a more conservative determination of measured concentrations and represents the lowest level that the laboratory determines quantitative information can be routinely reported, based on specified limits of precision and accuracy during routine laboratory operating conditions. Detection levels and measured concentrations used in this report correspond to the MDLs. During the January 2009 through May 2010 period, laboratory detection levels for the pesticides and pesticide degradates detected in samples from LWRM Network wells ranged from 0.04 to 0.6 microgram per liter $(\mu \mathrm{g} / \mathrm{L})$, except for metalaxyl ( 1 to $2 \mu \mathrm{g} / \mathrm{L}$ ).

Quality-control samples included blind replicates, field blanks, and spike samples (spiked with pesticide compounds of known concentration). For all laboratory analytes, about 95 percent of replicate samples were within 10 percent relative difference, and 80 percent of replicate samples were within 1 percent relative difference. Mean percent recovery of detected pesticide compounds in spiked samples typically ranged from about 88 to 103 percent of expected concentration (table 5). The low mean recovery (53 percent) for deisopropylatrazine (DIA), the only pesticide compound with a mean percent recovery below 80 percent (table 5), indicates the potential for a lower likelihood of detection if sample concentrations were near the laboratory reporting limit, and possible underestimation of detected concentrations.
Table 5. Spike recovery results for selected pesticides and pesticide degradates analyzed in groundwater samples, January 2009 through May 2010.

[Pesticide degradates are shown in italics.]

\begin{tabular}{|c|c|c|c|c|c|}
\hline \multirow{2}{*}{$\begin{array}{l}\text { Pesticide } \\
\text { compound }\end{array}$} & \multicolumn{4}{|c|}{ Percent recovery } & \multirow[b]{2}{*}{$\begin{array}{c}\text { Number of } \\
\text { samples }\end{array}$} \\
\hline & Mean & $\begin{array}{l}\text { Standard } \\
\text { deviation }\end{array}$ & $\begin{array}{l}\text { Mini- } \\
\text { mum }\end{array}$ & $\begin{array}{c}\text { Maxi- } \\
\text { mum }\end{array}$ & \\
\hline Aldicarb, dissolved & 101.3 & 26.4 & 59 & 197 & 94 \\
\hline $\begin{array}{l}\text { Aldicarb sulfoxide, } \\
\text { dissolved }\end{array}$ & 102.3 & 25.8 & 74 & 197 & 94 \\
\hline $\begin{array}{l}\text { Aldicarb sulfone, } \\
\text { dissolved }\end{array}$ & 99.9 & 27.4 & 9 & 199 & 94 \\
\hline Bromacil & 98.4 & 15.1 & 36 & 120 & 121 \\
\hline $\begin{array}{l}\text { Deethyl atrazine } \\
\text { (DEA) }\end{array}$ & 80.3 & 26.3 & 60 & 260 & 58 \\
\hline $\begin{array}{l}\text { Deisopropyl atrazine } \\
\text { (DIA) }\end{array}$ & 53.3 & 14.7 & 18 & 170 & 101 \\
\hline $\begin{array}{l}\text { Demethyl } \\
\text { norflurazon }\end{array}$ & 98.6 & 14.5 & 38 & 118 & 121 \\
\hline Diuron & 95.0 & 16.4 & 17 & 120 & 119 \\
\hline Imidacloprid & 102.9 & 17.7 & 44 & 138 & 131 \\
\hline Metalaxyl & 96.6 & 15.1 & 27 & 120 & 121 \\
\hline Norflurazon & 96.4 & 14.9 & 28 & 117 & 121 \\
\hline Oxamyl, dissolved & 93.8 & 26.0 & 42 & 200 & 94 \\
\hline Simazine & 99.4 & 17.5 & 27 & 136 & 113 \\
\hline Thiazopyr monoacid & 88.4 & 22.3 & 7.5 & 160 & 101 \\
\hline
\end{tabular}

Several constituents were detected in blank samples, typically in low concentrations, during the 2009-2010 sampling period. Chloride was detected in 5 of 25 field blanks at concentrations of 0.08 to 0.13 milligrams per liter $(\mathrm{mg} / \mathrm{L})$. Copper was detected above the $6.2 \mu \mathrm{g} / \mathrm{L}$ reporting limit in 2 of 26 field blank samples ( 7.9 and $8.6 \mu \mathrm{g} / \mathrm{L})$. Demethyl norflurazon was detected in 1 of 26 field blanks at a concentration of $0.85 \mu \mathrm{g} / \mathrm{L}$; this represents the only occurrence of any pesticide parent or degradate in field blanks from LWRM Network wells during the 1999 to 2010 period.

Statistical comparisons between field and laboratory results, presented in data summaries, included the non-parametric Wilcoxon and Kruskal-Wallis tests to compare median values between groups using SAS software (SAS Institute, Inc., 2008). In these comparisons, censored values were assigned a rank commensurate with the detection level since, for a given analyte, the vast majority of the censored values had a constant detection level during the 2009-2010 period. In addition, a common censoring level was applied in some comparisons among analytes with differing laboratory detection levels to avoid potential bias. When detection levels differ between analytes, the analytes having lower reporting levels are apt to be detected more often solely due to the higher resolution of detection.

At the time the LWRM Network was established, all of the citrus land-use wells were surrounded completely by extensive, actively farmed citrus. Changes in agrichemical sources and (or) agrichemical management have occurred over time near some of the Network's citrus land-use wells and could potentially affect groundwater quality. Some of the apparent land-use and citrus-crop changes during 1999-2010 near several of the citrus land-use wells have included removal of citrus and conversion to either fallow land or to residential development; removal of old or diseased citrus and replanting with new nursery stock; and orchard decline 
or abandonment. To document land-use changes over time near the citrus land-use wells, within an approximate radius of 0.25 mile (mi), repeat photographs were taken in the field approximately annually, in addition to periodic onsite land-use assessments.

\section{Water-Quality Benchmarks}

Water-quality results from LWRM Network sampling were compared to several water-quality benchmarks, which serve as screening tools to protect drinking-water sources, minimize potential risk to human health, or to identify constituents that could warrant further study. These benchmarks (table 6, Excel file) included federally regulated enforceable primary drinking-water standards (USEPA maximum contaminant levels; MCLs), non-enforceable guidelines (USEPA lifetime health advisory levels (HALs) and USEPA secondary drinking-water regulations), USGS health-based screening levels (HBSLs), and Florida groundwater guidance concentrations (GCs), which include regulated standards and unregulated guidelines.

The USEPA secondary drinking-water regulations for inorganic constituents relate to cosmetic and aesthetic effects of these constituents in drinking water (U.S. Environmental Protection Agency, 2011). The HBSLs were developed by the USGS in collaboration with the USEPA and others, and represent benchmark concentrations of contaminants in water that, if exceeded, may be of potential concern for human health (Toccalino, 2007). The HBSLs supplement established Federal drinking-water guidelines, typically focusing on analytes for which guidelines are not listed or have not yet been defined.

The Florida groundwater GCs (table 6) are used by FDACS and other State agencies to identify water-quality constituents in groundwater that might warrant further study and (or) additional sampling. The Florida groundwater GCs correspond to the Florida MCLs (State of Florida, 2012) and to the USEPA MCLs and HALs (U.S. Environmental Protection Agency, 2011); for pesticides for which MCLs or HALs have not been defined, the Florida GCs for groundwater correspond to Florida's Groundwater Cleanup Target Levels associated with State statutes (University of Florida, 2005; State of Florida, 2005). The Florida groundwater GCs for parent pesticide compounds have been used as the GCs for their respective degradates and (or) parent-degradate sums.

Table 6 provides a summary of the human-health benchmarks for nitrate and selected pesticides and inorganic agrichemicals detected in groundwater samples from the LWRM Network wells, the USEPA classification of cancer risk, and a brief description of the pesticide uses. The difference between the Florida groundwater GC and the HBSL for norflurazon (table 6) reflects an adjustment incorporated into the HBSL to account for possible cancer risk - norflurazon has been classified as a possible carcinogen (U.S. Environmental Protection Agency, 2011).

\section{Rainfall and Groundwater Levels}

Annual rainfall totals during the 1999-2010 period of sampling of the LWRM Network included several notably wet and dry years compared to the 1932 through 2010 rainfall record at Archbold Biological Station in Venus, Fla. (fig. 2; Nancy Deyrup, Archbold Biological Station, written commun., May 5, 2003; National Oceanic and Atmospheric Administration, 2010). Archbold Biological Station has one of the longest climate-monitoring records on the Ridge. Annual rainfall from 1999 to 2009 ranged from 27 to 72 in. (fig. 2). Convective storms as well as tropical storm systems and hurricanes are sources of intense rainfall in this region and can result in substantial spatial variability in precipitation amounts.

Departures of annual rainfall from the long-term mean exceeded 30 percent during 5 years between 1999 and 2010, (fig. 3A), including 2002 and 2004, which were much wetter than average, and 2000, 2007, and 2009 which were much drier than average (fig. 2). During the late summer and early fall of 2004, the paths of three major hurricanes crossed the northern part of the study area (Bossak, 2004).

Some monthly totals at Archbold Biological Station during the 1999 through 2009 period were extremes for the 1932 through 2009 period of record. Totals for July 2001 and August 2006 were the highest rainfall on record for these months; and August 2000, February 2001, April 2006, and November 2008 totals were the lowest on record for these months. During 1999 through 2009, monthly rainfall totals were more than 10 inches (in.) during 14 months and exceeded 17 in. during 4 months (table 7), all of which occurred during the typical rainy season, June through September.

Important factors influencing groundwater levels in the surficial aquifer on Lake Wales Ridge are rainfall and groundwater pumpage (Yobbi, 1996; Spechler and Kroening, 2007). Water levels fluctuate seasonally in response to recharge from rainfall, evapotranspiration, lateral discharge of water to lakes and streams, and downward leakage of water to underlying aquifers. In the surficial aquifer underlying the Ridge, the water table is about 10- to 90 - $\mathrm{ft}$ higher than the potentiometric surface of the underlying intermediate aquifer and Upper Floridan aquifer, indicating the potential for downward leakage (Yobbi, 1996). Figure $3 B$ shows a time-series of water levels from January 1998 through January 2010 at two of the Network wells (in the surfical aquifer), compared to the 1998 through 2009 annual departures from long-term rainfall. Spechler and Kroening (2007) noted record or near record lows in 2001 for groundwater levels at some wells in the surficial aquifer in Polk County.

Patterns of water-level responses to recharge from rainfall can vary with depth to water table as illustrated in figure $3 B$ by comparing the water levels of the shallow well (North Lake Patrick, site 1, fig. 1) and the deep well (P-7 Watertank, site 30, fig. 1). During the 1998 through 2010 period, the shallow well (water-table depth about 25 to $30 \mathrm{ft}$ ) shows higher frequency, smaller magnitude water-level fluctuations compared to the lower frequency, smoother trend in the deeper well (water-table depth about 100 to $110 \mathrm{ft}$ ). The thicker unsaturated zone at the deeper well likely dampens the influence of short-term recharge events and results in a longer lag time in water-level response to recharge, especially following a dry periods. 


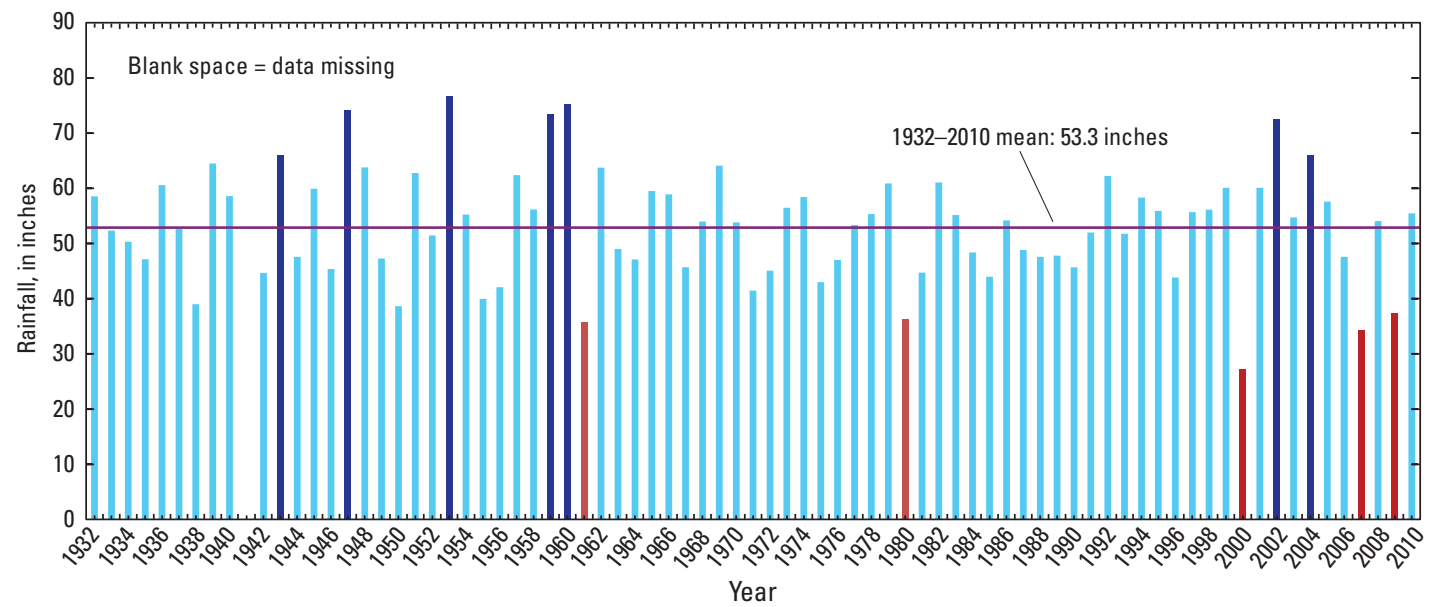

Figure 2. Long-term annual rainfall at Archbold Biological Station,1932 through 2010 (Nancy Deyrup, Archbold Biological Station, Venus, Florida, written commun., May 5, 2003; National Oceanic and Atmospheric Administration, 2010). Red bars indicate annual totals less than 38 inches, and dark blue bars indicate annual totals exceeding 65 inches.
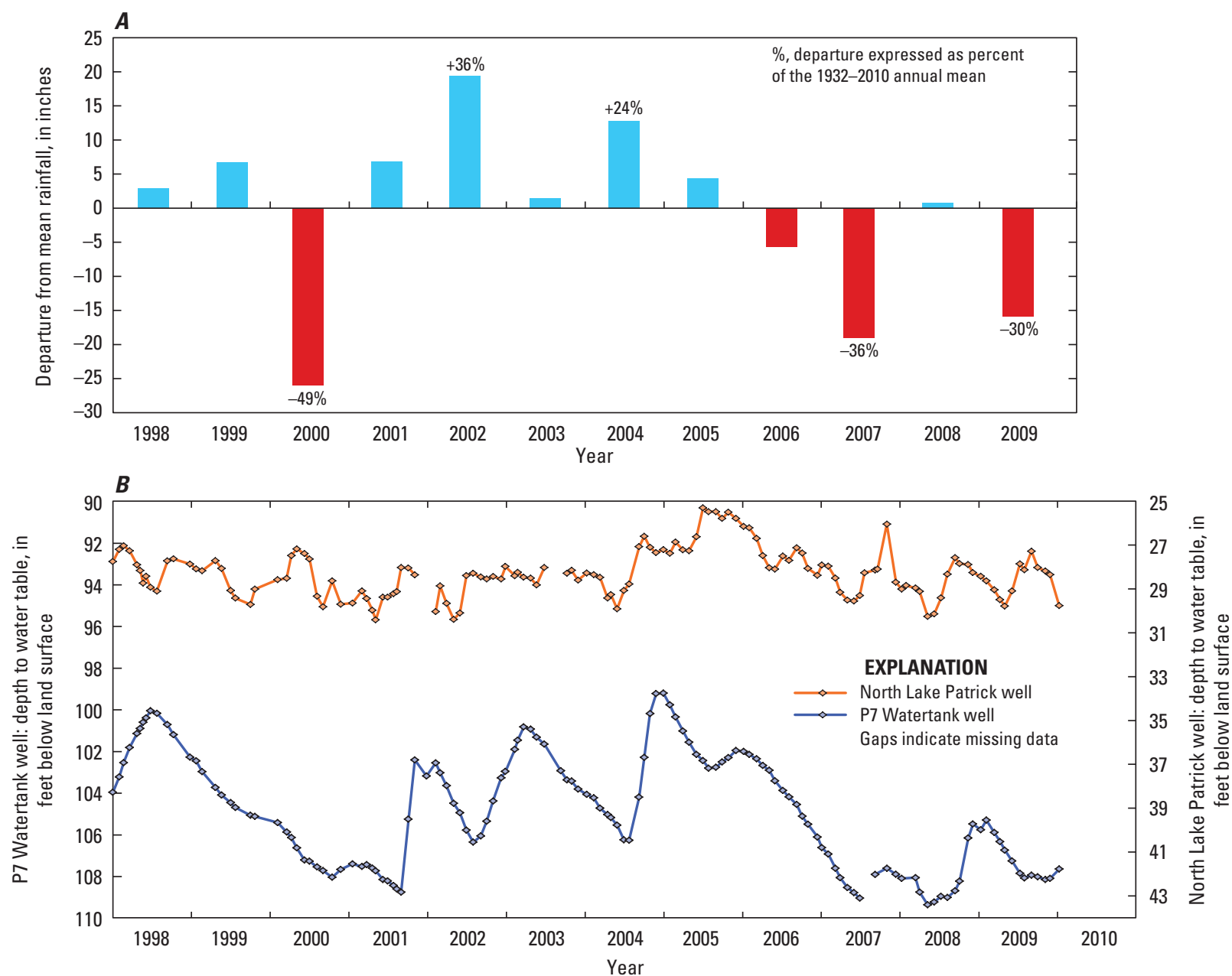

Figure 3. (A) Annual rainfall departures from the long-term mean compared to $(B)$ water-levels records from two wells with shallow and deep water tables. Annual rainfall is from Archbold Biological Station and the mean corresponds to the period 1932 through 2010 (Nancy Deyrup, Archbold Biological Station, Venus, Florida, written commun., May 5, 2003; National Oceanic and Atmospheric Administration, 2010). The well-screen interval is at a depth of 35 to 55 feet below land surface at the North Lake Patick well, and 125 to 145 feet at the P7 Watertank well. 
Table 7. Years and months during 1999-2009 when rainfall totals exceeded 10 inches at Archbold Biological Station near Venus, Florida (National Oceanic and Atmospheric Administration, 2010).

\begin{tabular}{|c|c|c|}
\hline Year & Month & Rainfall (inches) \\
\hline \multirow{2}{*}{1999} & June & 10.89 \\
\hline & August & 14.31 \\
\hline \multirow{2}{*}{2001} & July & 17.27 \\
\hline & September & 11.55 \\
\hline \multirow{3}{*}{2002} & June & 18.66 \\
\hline & July & 11.05 \\
\hline & August & 10.80 \\
\hline 2003 & June & 11.04 \\
\hline \multirow{2}{*}{2004} & August & 17.88 \\
\hline & September & 12.54 \\
\hline 2005 & June & 13.89 \\
\hline 2006 & August & 20.05 \\
\hline \multirow{2}{*}{2008} & July & 12.06 \\
\hline & August & 12.33 \\
\hline
\end{tabular}

\section{Pesticides and Selected Inorganic Agrichemical Results from the Citrus Land-Use Wells, January 2009 through May 2010}

Samples from the LWRM Network's citrus land-use wells during the period January 2009 through May 2010 were analyzed for the full suite of major and minor water chemistry and selected agricultural chemicals, as described under the section "Network Design and Methods." The results summarized in this section focus on a subset of the analyzed constituents, and include parent and degradate pesticides, nitrate, copper, and arsenic. Three of the sampling events (April 2009, October 2009, and April 2010) included all of the citrus land-use wells. In two sampling events (January 2009 and July 2009), the number of citrus land-use wells sampled was reduced from 30 to 23 (table 1) to accomodate the sampling of the additional non-citrus wells for the land-use study. In February 2010, six citrus land-use wells were sampled to maintain a quarterly sampling record for these wells (table 1).

During January 2009 through May 2010, 24 of the 37 pesticide compounds (28 parent pesticides and 9 degradates) analyzed in samples from citrus land-use wells were not detected (table 8). Water-quality results for pesticides, nitrate, arsenic, and copper during this period are shown in table 9 . A total of 13 pesticide compounds ( 8 parent pesticides and 5 degradates) were detected at citrus land-use wells. Compounds most frequently detected above a standardized censoring level of $0.5 \mu \mathrm{g} / \mathrm{L}$ included demethyl norflurazon (83 percent of wells), norflurazon (79 percent of wells), aldicarb sulfoxide (41 percent of wells), aldicarb sulfone (38 percent of wells), imidacloprid (38 percent of wells), and diuron (28 percent of wells). Copper and arsenic were detected in samples from 7 and 17 percent of the wells, respectively, although neither of these analytes exceeded Florida GCs for groundwater (table 9).

Three of the pesticide compounds exceeded the USEPA MCL and Florida GCs for groundwater: aldicarb, aldicarb sulfone, aldicarb sulfoxide, as well as the sum of these compounds (table 9). The majority of these exceedances occurred for the aldicarb degradates, ranging from 18 to 24 percent of samples analyzed. Florida statutes that restrict the distance of aldicarb applications to potable wells (State of Florida, 1997) could result in lower concentrations of the parent compound and degradates near potable wells compared to monitoring wells, where the restrictions do not apply. In one or two of the 136 or 137 samples analyzed (depending on analyte), concentrations exceeded 0.5 of the Florida groundwater GCs for bromacil, diuron, norflurazon, and the sum of norflurazon plus its degradate. The HBSLs were exceeded for norflurazon (29 percent of samples) and for diuron ( 7 percent of samples), with 39 percent of norflurazon samples exceeding 0.5 of the HBSL level. Nitrate exceeded the Florida groundwater GC (and USEPA MCL) of $10 \mathrm{mg} / \mathrm{L}$ in 68 percent of the samples, and in one or more samples from 21 (72 percent) of the 29 citrus land-use wells.

Table 8. Analyzed pesticides and pesticide degradates that were not detected in samples from citrus land-use wells, January 2009 through May 2010, and laboratory detection levels during this period. Analyzed sample fractions are total unless otherwise noted.

[Pesticide degradates are shown in italics.]

\begin{tabular}{|c|c|}
\hline Pesticide compound & $\begin{array}{c}\text { Detection level } \\
\text { (microgram per liter) }\end{array}$ \\
\hline $2,4-\mathrm{D}^{1}$ & $2.7,13$ \\
\hline Alachlor & 2 \\
\hline Atrazine & 0.2 \\
\hline Bentazon & 0.04 \\
\hline Chlorpyrifos & 0.2 \\
\hline Clothianidin & 0.04 \\
\hline Deethyl Atrazine (DEA) & 0.4 \\
\hline Dicamba $^{1}$ & $2.7,13$ \\
\hline Dimethoate & 0.2 \\
\hline Ethion & 0.1 \\
\hline Fenamiphos & 0.2 \\
\hline Fenamiphos sulfone & 0.2 \\
\hline Fenamiphos sulfoxide & 0.2 \\
\hline Iprodione & 4 \\
\hline Malathion & 0.2 \\
\hline MCPP (Mecoprop-p) ${ }^{1}$ & $2.7,13$ \\
\hline Methomyl, dissolved & 0.1 \\
\hline Metolachlor & 2 \\
\hline Metribuzin & 0.4 \\
\hline Oryzalin & 16 \\
\hline Thiamethoxam & 0.4 \\
\hline Thiazopyr & 0.04 \\
\hline Triclopyr ${ }^{1}$ & $2.7,13$ \\
\hline
\end{tabular}

${ }^{1}$ Analyzed routinely in a subset of 10 of the network wells in citrus land use. 


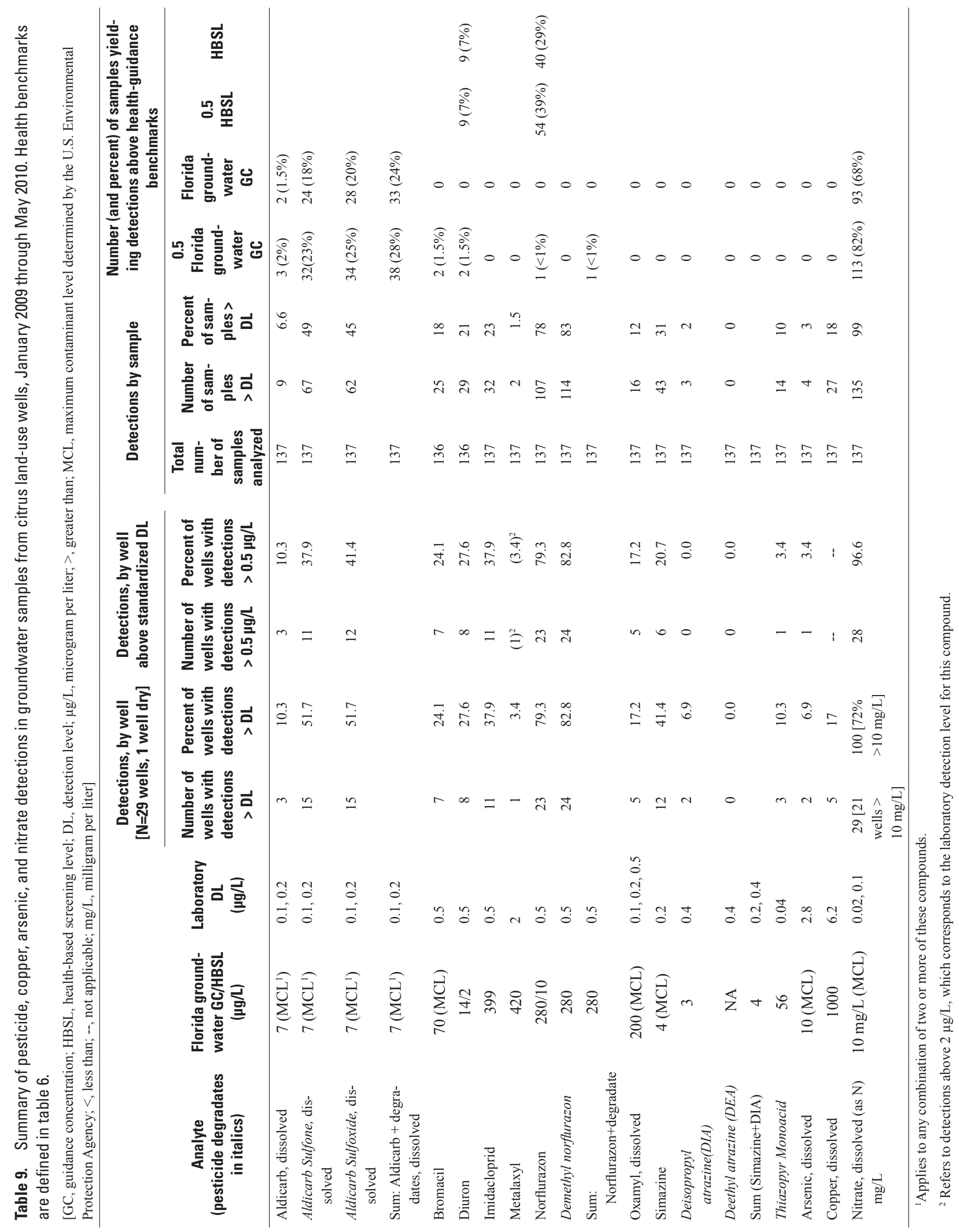




\section{Comparison of Results from Citrus and Non-Citrus Land-Use Wells, 2009}

In January through February 2009 and in July through August 2009, 8 of the non-citrus wells were sampled along with 23 of the LWRM Network citrus land-use wells. The following comparison between citrus and non-citrus land use wells includes well construction and the results of water-quality sampling during these two events.

\section{Well Construction}

The well depths of the citrus and non-citrus wells were similar with both groups having a median of $55 \mathrm{ft}$ (table 10). The median depth to the water table was 39.1 $\mathrm{ft}$ among the citrus wells compared to $10.4 \mathrm{ft}$ among the non-citrus wells, as measured during the January through February 2009 sampling event (table 10). The difference between the groups was marginally significant $(p=0.08)$. Length of screened interval ranged from 10 to $20 \mathrm{ft}$ in the citrus land-use wells, and from 3 to $20 \mathrm{ft}$ in the non-citrus wells (table 2). Sampling depth was measured in two ways, as the depth of the top and of the mid-point of the well screen below the water table. The range in these sampling depths was similar between the citrus and non-citrus well groups, both of which ranged from near the water table to about $40 \mathrm{ft}$ below the water table (table 10). Sampling depth was denoted as the water table when the top or mid-point of the well screen was at or above the water table. The median values of the sampling depths among the citrus land-use wells were about $20 \mathrm{ft}$ closer to the water table $(\mathrm{p}<0.05)$ compared to the medians for the non-citrus wells (table 10).

Table 10. Summary of well construction and sampling depths at wells sampled in the land-use comparison. Sampling depths and depths to water-table correspond to the Jan.-Feb. 2009 sampling event.

\begin{tabular}{|c|c|c|c|c|c|c|c|c|c|}
\hline \multirow{2}{*}{$\begin{array}{l}\text { Land-use } \\
\text { classifica- } \\
\text { tion }\end{array}$} & \multirow[t]{2}{*}{$\begin{array}{l}\text { Number } \\
\text { of wells }\end{array}$} & \multicolumn{2}{|c|}{ Well depth (feet) } & \multicolumn{2}{|c|}{$\begin{array}{l}\text { Depth to water } \\
\text { table (feet) }\end{array}$} & \multicolumn{2}{|c|}{$\begin{array}{l}\text { Top-of-screen sampling } \\
\text { depth, relative to water } \\
\text { table (feet) }\end{array}$} & \multicolumn{2}{|c|}{$\begin{array}{c}\text { Mid-screen sampling } \\
\text { depth, relative to } \\
\text { water table (feet) }\end{array}$} \\
\hline & & Median & Range & Median & Range & Median & Range & Median & Range \\
\hline Citrus & 23 & 55 & $19-150$ & 39.1 & $4.2-107$ & 1 & $\begin{array}{c}\text { Water } \\
\text { table-38 }\end{array}$ & 6 & $\begin{array}{c}\text { Water } \\
\text { table-43 }\end{array}$ \\
\hline Non Citrus & 8 & 55 & $23-110$ & 10.4 & $5.1-82$ & 19 & $5-32$ & 25 & $10-42$ \\
\hline
\end{tabular}

\section{Physical Properties, Inorganic Constituents, and Nutrients}

A summary of the physical properties, inorganic constituents, and nutrients in groundwater samples, and the statistical comparison between water quality in the citrus and non-citrus land-use well groups appear in table 11. Comparison of the median values for each land-use group to the USEPA drinking-water benchmarks indicates nitrate (as N) and nitrate plus nitrite (as N) in samples from the citrus land-use wells exceeded the primary standard $(10 \mathrm{mg} / \mathrm{L})$. The USEPA secondary standards (U.S. Environmental Protection Agency, 2011), which relate to cosmetic or aesthetic effects of drinking water, include $\mathrm{pH}$, aluminum, and manganese. In both the citrus and the non-citrus well groups the median $\mathrm{pH}$ was below the minimum secondary standard range ( 6.5 to 8.5 standard units). In non-citrus wells, median aluminum concentration exceeded the lower limit of the secondary standard range (50 to $200 \mu \mathrm{g} / \mathrm{L}$ ); in citrus wells, median manganese exceeded the secondary standard $(50 \mu \mathrm{g} / \mathrm{L})$, and median aluminum exceeded the upper limit of the secondary standard range (table 11). The $\mathrm{pH}$ of groundwater in the surficial aquifer is naturally low and similar to that of rainwater, in many parts of Florida due to its low buffering capacity (Upchurch, 1998). Rainwater $\mathrm{pH}$ for sites in the vicinity of central Florida is typically in the range 4.6 to 5.2 standard units (National Atmospheric Deposition Program, 2012).

To assess potential effects of seasonal influences on water quality, the median values of physical properties and concentrations of chemical constituents in samples were compared between the January through February 2009 and the July through August 2009 sampling events for the citrus and non-citrus well groups (table 11). Only 3 constituents (ammonia, fluoride, and strontium) of the 27 physical properties and inorganic constituents showed significant seasonal differences $(\mathrm{p}<0.05)$ between the two sampling events. Therefore, for the land-use comparisons, separate analyses by sampling event were performed for these 3 constituents, and for all other analytes the samples from both events were combined (table 11). 
Table 11. Comparison of physical properties, nutrients, and inorganic constituent concentrations between groundwater samples from citrus and non-citrus land-use wells.

[median values in bold exceeded primary (P) or secondary (S) drinking-water regulations; values in blue indicate median values were statistically different at the 2-sided $0.05 \mathrm{p}$-level; 1-sided and 2-sided p-values are shown if the 2-sided p-value was between 0.05 and 0.1 ; citrus, citrus land-use wells; non-citrus, noncitrus land-use wells; mg/L, milligram per liter; ns, not significant; $\mu \mathrm{g} / \mathrm{L}$, microgram per liter; <, less than; >, greater than; Pt-Co, platinum-cobalt unit; mp, measuring point, approximately at land surface; ft, feet; MS, marginally significant; FDACS, Florida Department of Agriculture and Consumer Services; SU, standard units; $\mu \mathrm{S} / \mathrm{cm}$, microsiemens per centimeter; deg. C, degrees Centigrade; NTU, nephelometric turbidity units]

\begin{tabular}{|c|c|c|c|c|c|c|c|}
\hline Analyte & Units & $\begin{array}{c}\text { 2-sided p-value } \\
\text { (1-sided/2- } \\
\text { sided) }\end{array}$ & $\begin{array}{c}\text { Number of } \\
\text { samples } \\
\text { (citrus) }\end{array}$ & $\begin{array}{c}\text { Number of } \\
\text { samples } \\
\text { (non-citrus) }\end{array}$ & $\begin{array}{l}\text { Median } \\
\text { (citrus) }\end{array}$ & $\begin{array}{c}\text { Median } \\
\text { (non-citrus) }\end{array}$ & $\begin{array}{c}\text { Difference } \\
\text { between me- } \\
\text { dians [citrus } \\
\text { - non-citrus] }\end{array}$ \\
\hline Aluminum (dissolved) & $\mu \mathrm{g} / \mathrm{L}$ & $<0.02$ & 46 & 16 & $\mathbf{5 0 7 . 5 ^ { \mathrm { s } }}$ & $121.50^{\mathrm{S}}$ & 386.00 \\
\hline Ammonia (as N) (dissolved) & $\mathrm{mg} / \mathrm{L}$ & $<0.001$ & 46 & 16 & $<0.008$ & 0.24 & $>-0.23$ \\
\hline Jan.-Feb. 2009 sampling event & $\mathrm{mg} / \mathrm{L}$ & 0.01 & 23 & 8 & 0.006 & 0.25 & -0.24 \\
\hline Calcium (dissolved) & $\mathrm{mg} / \mathrm{L}$ & $<0.001$ & 46 & 16 & 22.8 & 2.67 & 20.14 \\
\hline Carbon-organic (total) & $\mathrm{mg} / \mathrm{L}$ & $<0.007$ & 46 & 16 & 1.5 & 5.65 & -4.15 \\
\hline Chloride (dissolved) & $\mathrm{mg} / \mathrm{L}$ & $<0.001$ & 46 & 16 & 19.55 & 6.55 & 13.00 \\
\hline Color (dissolved) & $\mathrm{Pt}-\mathrm{Co}$ & $<0.001$ & 46 & 16 & 0.95 & 12.45 & -11.50 \\
\hline Depth to water (from mp) (Jan.-Feb. 2009) & $\mathrm{ft}$ & $\operatorname{MS}(0.04 / 0.08)$ & 23 & 8 & 39.14 & 10.44 & 28.70 \\
\hline Dissolved oxygen (total) & $\mathrm{mg} / \mathrm{L}$ & $\operatorname{MS}(0.04 / 0.09)$ & $19 *$ & $7 *$ & 7.34 & 0.79 & 6.55 \\
\hline Iron (dissolved) & $\mu \mathrm{g} / \mathrm{L}$ & $<0.001$ & 46 & 16 & 12.85 & 228.5 & -215.65 \\
\hline Magnesium (dissolved) & $\mathrm{mg} / \mathrm{L}$ & $<0.001$ & 46 & 16 & 10.85 & 1.09 & 9.76 \\
\hline Manganese (dissolved) & $\mu \mathrm{g} / \mathrm{L}$ & $<0.004$ & 46 & 16 & $108.5^{\mathrm{s}}$ & 10.16 & 98.34 \\
\hline Nitrate (as N) (dissolved) [FDACS lab] & $\mathrm{mg} / \mathrm{L}$ & $<0.001$ & 46 & 16 & $15.0^{\mathrm{P}}$ & 0.02 & 14.98 \\
\hline Nitrate+Nitrite (as N) (dissolved) & $\mathrm{mg} / \mathrm{L}$ & $<0.001$ & 46 & 16 & $13.4^{\mathrm{P}}$ & 0.01 & 13.39 \\
\hline Nitrite (as N) (dissolved) & $\mathrm{mg} / \mathrm{L}$ & MS (0.04/0.07) & 46 & 16 & $<0.005$ & $<0.005$ & non-citrus $>$ citrus \\
\hline Nitrogen- Total (dissolved) & $\mathrm{mg} / \mathrm{L}$ & $<0.001$ & 46 & 16 & 13.8 & 0.61 & 13.19 \\
\hline $\mathrm{pH}$ & SU & $\operatorname{MS}(0.03 / 0.06)$ & $36^{*}$ & 16 & $4.91^{\mathrm{s}}$ & $5.81^{\mathrm{s}}$ & -0.90 \\
\hline pH (Jan.-Feb. 2009 sampling event) & SU & MS $(0.03 / 0.06)$ & 23 & 8 & $4.62^{\mathrm{S}}$ & $5.41^{\mathrm{s}}$ & -0.79 \\
\hline Phosphorus-total (dissolved) & $\mathrm{mg} / \mathrm{L}$ & ns & 46 & 16 & 0.012 & 0.011 & 0.001 \\
\hline Potassium (dissolved) & $\mathrm{mg} / \mathrm{L}$ & $<0.001$ & 46 & 16 & 14.9 & 0.83 & 14.07 \\
\hline Sulfide (total) & $\mathrm{mg} / \mathrm{L}$ & $<0.001$ & 46 & 16 & $<0.1$ & 0.215 & $>-0.115$ \\
\hline Temperature (total) & deg.C & ns & $19 *$ & $7 *$ & 26.4 & 25.86 & 0.54 \\
\hline Turbidity (total) & NTU & ns & 46 & 16 & 0.74 & 0.46 & 0.28 \\
\hline
\end{tabular}

*, indicates this group represents a subset of samples in which the analyte was not measured in all samples.

s, indicates exceedance of U.S. Environmental Protection Agency secondary regulation for drinking water (non-enforceable).

P, indicates exceedance of U.S. Environmental Protection Agency primary standard (MCL) for drinking water.

E, estimated 
A number of inorganic constituent concentrations differed between the citrus and non-citrus land-use areas. Compared to non-citrus areas, samples from the wells in citrus land-use yielded greater $(\mathrm{p}<0.05)$ concentrations of: aluminum, chloride, fluoride, magnesium, manganese, nitrate plus nitrite, total nitrogen $(\mathrm{N})$, potassium, strontium, sulfate, and specific conductance. Elevated concentrations of calcium, magnesium, chloride, sulfate, potassium, and nitrate, and higher specific conductance have been documented in other studies of groundwater and lakes in ridge citrus compared to non-citrus areas (Stauffer, 1991; Sacks and others, 1998; Choquette and Kroening, 2009). These studies noted agrichemicals, including fertilizers, soil amendments, and some pesticide formulations, as well as irrigation water from the Upper Floridan aquifer as potential sources of these chemicals.

More than 93 percent of citrus orchards in Polk and Highlands Counties are irrigated (Florida Agricultural Statistics Service, 1998), and in some areas the irrigation water is withdrawn from the typically more highly mineralized waters from the Upper Floridan aquifer. However, concentrations of potassium and sulfate in groundwater from the Upper Floridan aquifer in the Lake Wales Ridge region (Spechler and Kroening, 2007; Spechler, 2010) are typically lower than the concentrations observed in the citrus land-use wells. Also, well and casing depths of the permitted supply wells on the Ridge are generally shallower in Highlands County than in Polk County (Choquette and Sepulveda, 2000), indicating the possibility of proportionally fewer Upper Floridan irrigation wells in the southern part of the Ridge compared to the northern part. Additional data are needed to fully evaluate the influence of irrigation sources versus agrichemical applications in increasing the concentrations of some of these inorganic constituents in the surficial aquifer underlying the citrus orchards. A complicating factor is a process known as chemigation, a means of applying agrichemicals by adding them to the irrigation waters (Boman, 2002).

Constituents showing higher $(\mathrm{p}<0.05)$ concentrations in groundwater underlying non-citrus compared to citrus land-use areas included total organic carbon, color, iron, sulfide, and ammonia-N. Possible causes for the higher concentrations of these constituents could be related to differences in soils and geologic deposits in the vicinity of these wells, in addition to the typically deeper sampling depths (below the water table) at the non-citrus wells (table 10). Differences in reduction/oxidation (redox) conditions are influenced by and can contribute to variations in concentrations of some of these constituents by affecting pathways of microbial chemical breakdown (McMahon and Chapelle, 2008). Of the non-citrus wells, dissolved-oxygen concentrations were greater than $7 \mathrm{mg} / \mathrm{L}$ at two wells (site $\mathrm{NC} 1$ and site $\mathrm{NC} 2$ ) and $<1 \mathrm{mg} / \mathrm{L}$ at the remaining six wells. Locally elevated iron concentrations are not uncommon in the surficial aquifer on the Ridge (Florida Department of Environmental Protection, 2006).
Samples from the non-citrus land-use wells typically yielded low concentrations of nitrate (as $\mathrm{N}$ ) and phosphorus (as P; table 11). Nitrate concentrations were $<0.04 \mathrm{mg} / \mathrm{L}$ in samples from six of the eight non-citrus wells. Two of the wells, Ridge Wrap P-4 (site NC2) and the USGS Shallow Observation well (site NC1), yielded nitrate concentrations of 2 to 3 , and 0.8 to $1.0 \mathrm{mg} / \mathrm{L}$, respectively. Samples from these wells also contained higher dissolved-oxygen values ( $>7 \mathrm{mg} / \mathrm{L})$, which can contribute to higher nitrate concentrations by limiting potential for denitrification (McMahon and Chapelle, 2008), but citrus land use in the vicinity of these wells, as discussed in the section "Pesticides and Pesticide Degradates", could also be a source of nitrate.

\section{Pesticides and Pesticide Degradates}

Of the 30 pesticides and degradates analyzed during the two sampling events, the non-citrus land-use wells yielded only two pesticide detections in one of the eight wells sampled, in comparison to multiple detections in 22 of 23 citrus land-use wells, which yielded a median of 4 pesticide compounds per well (fig. 4). The non-citrus well Ridge Wrap P-4 (site NC2) yielded low concentrations of norflurazon $(1.0$ and $1.7 \mu \mathrm{g} / \mathrm{L})$ and demethyl norflurazon (3.4 and $5.9 \mu \mathrm{g} / \mathrm{L}$ ). Only one of the sampled citrus land-use wells, Muncie Road (site 18), did not yield any pesticide detections. This well also has been noted as yielding anomalously low groundwater nitrate concentrations compared to other Ridge citrus monitoring wells (Wheaton and Graham, 2000). Citrus orchards surrounding the Muncie Road well were removed between 2004 and 2005 and converted to rural residential development.

Summary statistics for pesticide, nitrate, arsenic, and copper concentrations in samples from the citrus and the non-citrus land-use wells are shown in table 12. A total of 12 pesticide compounds ( 8 parent compounds and 4 degradates) were detected above laboratory detection levels in 2 to 95 percent of the samples from the citrus land-use wells. Those most frequently detected were demethyl norflurazon and norflurazon (95 and 88 percent of samples, respectively), aldicarb sulfone and aldicarb sulfoxide (53 and 47 percent of samples, respectively), and simazine ( 35 percent of samples). Table 12 also shows the median and (or) maximum concentrations of samples from the citrus wells, by analyte, that exceeded either the Florida groundwater GCs (aldicarb sulfone, aldicarb sulfoxide, and nitrate), 0.5 of the Florida groundwater GC (aldicarb, bromacil, and diuron), or the HBSLs (diuron and norflurazon).

Citrus orchards represent potential sources of elevated groundwater nitrate concentrations $(0.8$ to $3.0 \mathrm{mg} / \mathrm{L})$ in samples from two LWRM Network non-citrus land-use wells (fig. 5, the USGS Shallow Observation well (site NC1) and the Ridge Wrap P-4 well (site NC2)), and 
detections of norflurazon and demethyl norflurazon from one of the wells (Ridge Wrap P-4). Citrus orchards were identified on the basis of aerial images taken intermittently between February 1995 and December 2010 (Google Earth, Inc., 2011). Active (as of December 2010) or recently active citrus orchards (fig. 5) were located about 0.14 and $0.22 \mathrm{mi}$ south and east, respectively, of the USGS Shallow Observation well (site NC1) and about 0.16 to $0.18 \mathrm{mi}$ to the north, northeast, and east of the Ridge Wrap P-4 well (site NC2). Possible fertilizer applications in areas of residential or commercial development (fig. 5) could be additional sources of nitrate. Fertilizer typically is not applied in pine tree plantations in this region (Robin Holland, Division of Forestry, Florida Department of Agriculture and Consumer Services, oral commun., November 2, 2012). Norflurazon is not labled for use in Florida in areas of residential/commercial development or in pine plantations; however, its use is allowed in non-crop areas of agricultural lands, such as ungrazed fencelines, equipment lots, and ditchbanks (R. Scott Freiwald, Florida Department of Agriculture and Consumer Services, written commun., November 2, 2012).

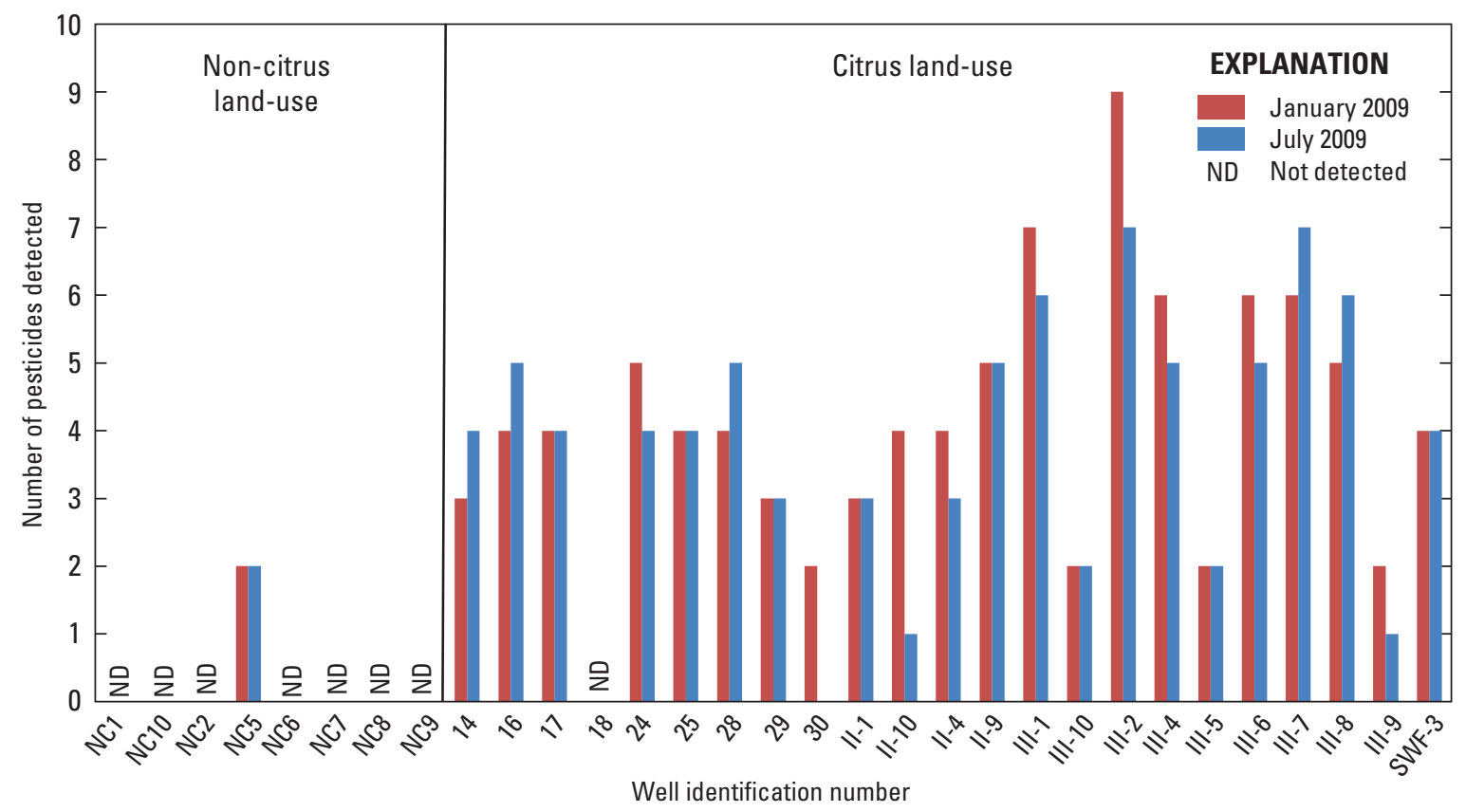

Figure 4. Comparison between pesticide detection frequencies in samples from citrus and non-citrus land-use wells during the January and July 2009 sampling events. 


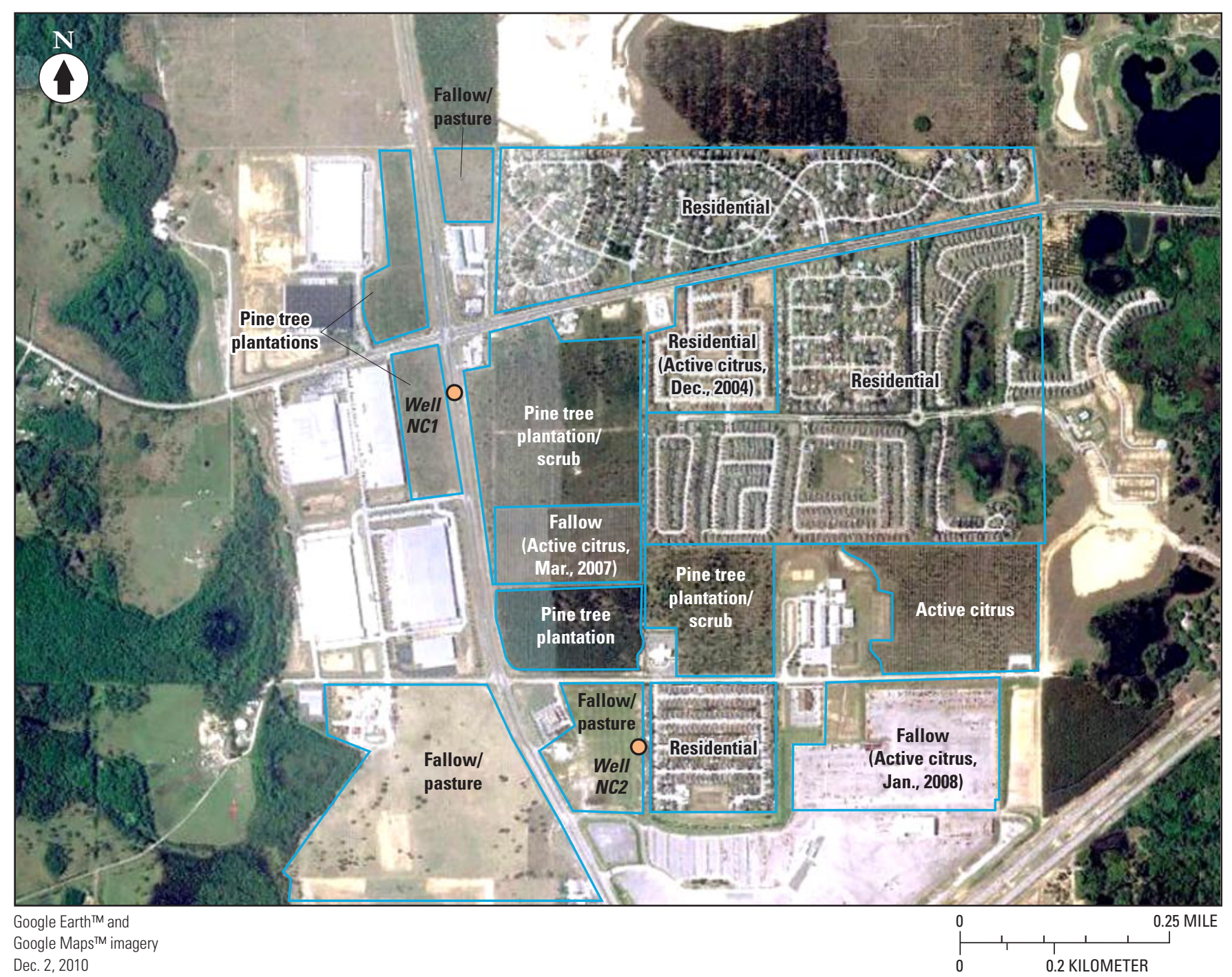

Figure 5. Land use in the vicinity of the USGS Shallow Observation Well (site NC1) on US Highway 27 and the Ridge WRAP P4 well (site NC2), on December 2, 2010. 


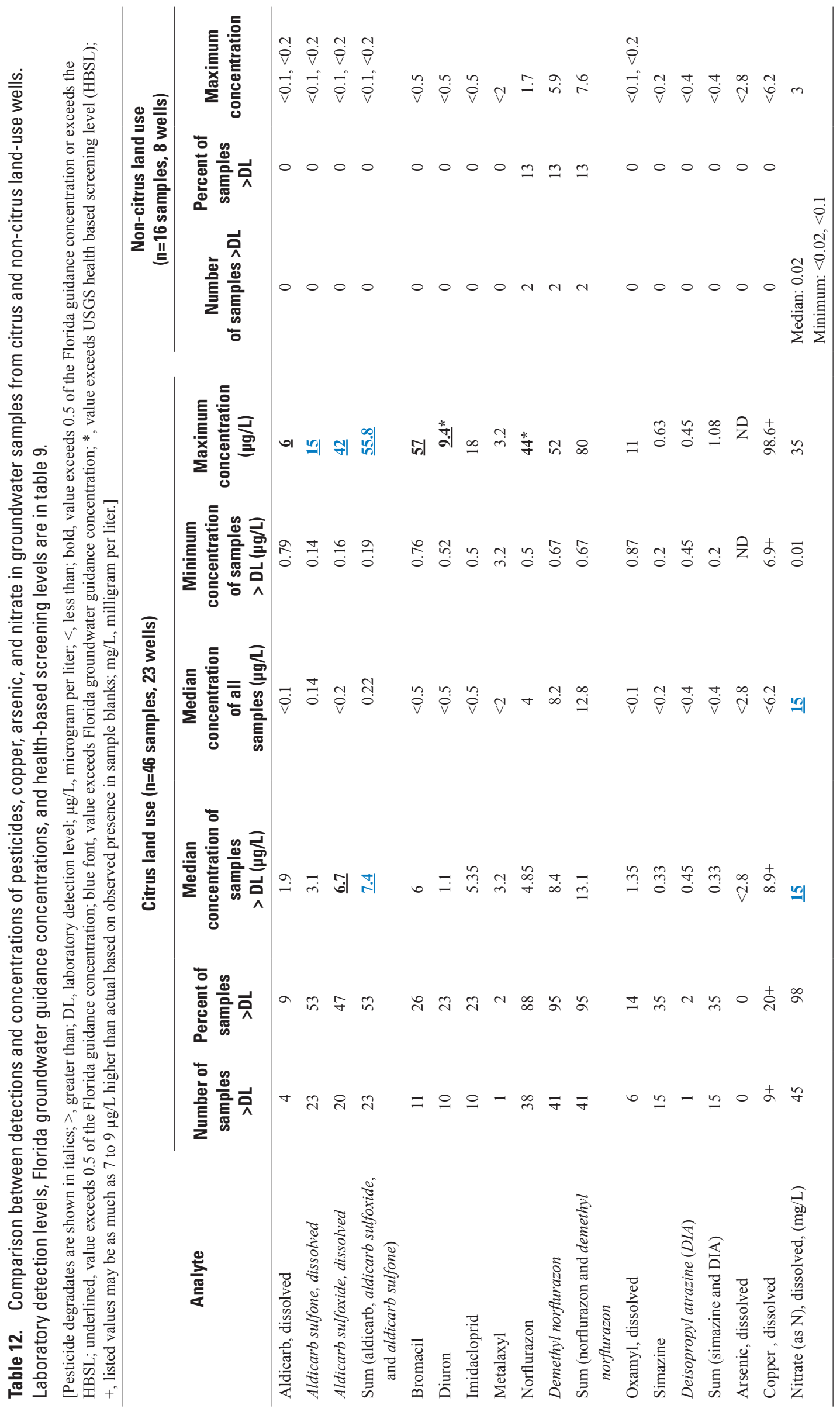




\section{Summary}

This report provides summaries of well characteristics, water-quality analyses and laboratory methods, and the complete sampling history from 1989 through May 2010 for the Lake Wales Ridge Monitoring (LWRM) Network, which currently includes 40 wells in the unconfined surficial aquifer underlying one of the principal citrus-growing regions of Florida. Water in the surficial aquifer flows into numerous groundwater seepage lakes on the Lake Wales Ridge, provides drinking water for rural domestic wells, and also ultimately recharges the underlying Upper Floridan aquifer, the principal municipal drinking-water supply in this region. During the 1999 through May 2010 period, most of the 30 citrus land-use wells in the LWRM Network were sampled on a quarterly basis for water quality including major water chemistry, nutrients, selected inorganic constituents, and 37 parent pesticides and degradates. The LWRM Network represents one of the few regional-scale, long-term ( $>10$ years) monitoring programs nationally that includes quarterly sample collection, documenting the temporal variability of pesticides in groundwater.

This report summarizes water-quality sampling results for January 2009 through May 2010, including 30 of the LWRM Network's citrus land-use wells, first sampled between 1989 and 2001, and eight non-citrus land-use monitoring wells, which were added to the Network in 2009. The report includes a comparison of land-use effects on groundwater quality underlying citrus and non-citrus areas on the basis of two sampling events in 2009.

In samples from the LWRM Network's 30 citrus land-use wells during 2009 through May 2010, 13 pesticide compounds ( 8 parent pesticides and 5 degradates) were detected. Those most frequently detected above a common $0.5-\mu \mathrm{g} / \mathrm{L}$ censoring level included: demethyl norflurazon (83 percent of wells), norflurazon (79 percent), aldicarb sulfoxide (41 percent), aldicarb sulfone (38 percent), imidacloprid (38 percent), and diuron (28 percent). In these samples, three of the pesticide compounds exceeded the USEPA MCL and Florida groundwater guidance concentrations for: aldicarb, aldicarb sulfone, aldicarb sulfoxide, as well as the sum of these compounds, with exceedances ranging from 1.5 percent (aldicarb) to 24 percent (sum of aldicarb plus degradates) of the analyzed samples. The HBSLs, which are health-screening benchmarks for water quality, were exceeded for norflurazon (29 percent of samples) and for diuron (7 percent of samples). During the 2009 through May 2010 period, nitrate exceeded the USEPA MCL in 68 percent of samples from the citrus land-use wells.

In the comparison of land-use effects on water quality, concentrations of a number of inorganic constituents were significantly higher $(\mathrm{p}<0.05)$ in groundwater samples (collected in January through February 2009 and in July through August 2009) from wells in the surficial aquifer surrounded by citrus land use compared to those in non-citrus land-use areas. Higher concentrations of calcium, magnesium, chloride, sulfate, potassium, nitrate (as N), total nitrogen, aluminum, manganese, and strontium, as well as specific conductance, in groundwater underlying the citrus land-use areas likely reflect the influence of agrichemical applications, as well as irrigation and site differences such as soils and groundwater redox (oxidation-reduction) conditions. Samples from the 23 citrus land-use wells yielded detections of 12 of 30 targeted parent pesticides and degradates, and all except one of these wells yielded one or more pesticide detections. Compared to a median of four pesticides and degradates detected per well in areas of citrus land use, only one of the eight sampled wells in non-citrus land use yielded pesticide detections consisting of one pesticide and its degradate; citrus orchards in proximity to this well are likely sources of these detections.

Monitoring of groundwater in the LWRM Network wells over time has documented the influence of land-use activities, as well as temporal and spatial variations in groundwater quality in the surficial aquifer. These variations likely reflect changes in agrichemical usage patterns, land use, establishment of regulatory restrictions on agrichemicals and use of new and alternative chemicals, as well as variations in groundwater recharge associated with climatic variability. Some recent changes in agrichemical usage patterns that have the potential to impact groundwater quality include the increased use of insecticides to address the spread of citrus greening disease, and the discontinued use in citrus of a widely applied nematicide and insecticide (aldicarb). Continued monitoring of the LWRM Network wells will assist in protecting drinking-water resources and in assessing the effects of all of these factors, as well as future changes in these factors, on groundwater quality in this highly vulnerable aquifer underlying an important citrus-production area of Florida.

\section{References Cited}

Boman, B.J., 2002, ed., Water and Florida citrus: Use, regulation, irrigation, systems, and management: Institute of Food and Agricultural Sciences, Gainesville, Fla., Special Publication, no. 281, $604 \mathrm{p}$.

Bossak, B.H., 2004, "X" marks the spot: Florida is the 2004 hurricane bull's-eye: EOS, American Geophysical Union, v. 85 , no. 50, p. 541 and 545.

Brlansky, R.H., Dewdney, M.M., and Rogers, M.E., 2012, 2012 Florida Citrus Pest Management Guide: Huanglongbing (Citrus Greening): University of Florida Institute of Food and Agricultural Sciences, Document PP-225, 3 p. (Also available at: http://edis.ifas.ufl.edu/pdffiles/CG/ CG08600.pdf) 
Brock, M., and Rygiel, T., 2003, The determination of inorganic anions in water by ion chromatography: Florida Department of Agriculture and Consumer Services, Pesticides Laboratory, Tallahassee, Fla., 11 p.

Choquette, A.F., and Kroening, S.E., 2009, Water quality and evaluation of pesticides in lakes in the Ridge citrus region of central Florida: U.S. Geological Survey Scientific Investigations Report 2008-5178, 55 p. (Also available at $h t t p: / /$ pubs.er.usgs.gov/publication/sir20085178.)

Choquette, A.F., Moore, D.K., DeHaven, E.C., Haber, J.D., and Turner, R.M., 2003, A litmus area for transport of agricultural chemicals into ground water and lakes, central Florida, May 12-14, 2003, in Proceedings of the American Water Resources Association, 2003 Spring Specialty Conference-Agricultural Hydrology and Water Quality, Kansas City, Mo., Proceedings, AWRA Technical Publication Series No. TPS-03-01.

Choquette, A.F., and Sepulveda, A.A., 2000, Design of a shallow ground-water network to monitor agricultural chemicals, Lake Wales Ridge, Central Florida: U.S. Geological Survey Water-Resources Investigations Report 2000-4134, 35 p. (Also available at http://pubs.er.usgs.gov/publication/wri004134.)

Choquette, A.F., Turner, R.M., Haber, J.D., Lucas, P.A., Daiker, D.H., and DeHaven, E.C., 2005, Temporal variability of agricultural chemicals in ground water and implications for water-quality sampling design: American Water Resources Association, Proceedings of the 15th Annual Tennessee Water Resources Symposium, April 2005, p. 2B6-2B14. (Also available at http://fisc.er.usgs.gov/Lake_Wales_Ridge/.)

Fishel, F.M., 2005 (rev. 2009), Specifically regulated pesticides in Florida - Bromacil: Florida Cooperative Extension, Institute of Food and Agricultural Sciences, University of Florida, UF/IFAS EDIS (Electronic Data Information source) Publication No. PI-75, 1 p. (Also available at http://edis.ifas.ufl.edu/pi112.)

Florida Agricultural Statistics Service, 1998, 1997 Census of agriculture: Florida state level data, v. 1, chap. 1, pt. 9, (Also available at $h t t p: / / w w w . a g c e n s u s . u s d a . g o v /$ Publications/2007/Full_Report/Census_by_State/)

Florida Agricultural Statistics Service, 2011, Florida citrus statistics 2009-2010: U.S. Department of Agriculture, National Agricultural Statistics Service, $112 \mathrm{p}$. (Also available at http://www.nass.usda.gov/Statistics_by State/Florida/Publications/Citrus/fcs/2009-10/fcs0910.pdf.)

Florida Department of Agriculture and Consumer Services, 1995, Protocol guidelines for pesticide field studies in Florida: Tallahassee, Bureau of Pesticides, 33 p.
Florida Department of Environmental Protection, 2002, Department of Environmental Protection standard operating procedures for field activities: Florida Department of Environmental Protection Document DEP-SOP-001/01 [variously paged].

Florida Department of Environmental Protection, 2006, Water quality assessment report-Kissimmee River and Fisheating Creek: Florida Department of Environmental Protection, Division of Water Resource Management, Tallahassee, Fla., 472 p. (Also available at $h t t p: / / w w w . d e p . s t a t e . f l . u s / w a t e r$ ) basin411/kissimmee/assessment.htm.)

Florida Department of Environmental Protection, 2012a, Background Water Quality Monitoring Network database, accessed March 4, 2012, at http://www.dep.state.flus/water/monitoring/ bn_net.htm.

Florida Department of Environmental Protection, 2012b, Very Intense Study Area (VISA) database, accessed March 4, 2012, at http://www.dep.state.fl.us/water/monitoring/visa_net.htm.

German, E.R., 1996, Analysis of nonpoint-source ground-water contamination in relation to land use: Assessment of nonpointsource contamination in central Florida: U.S. Geological Survey Water-Supply Paper 2381-F, 60 p. (Also available at http://pubs.er.usgs.gov/publication/wsp2381F.)

Gilliom, R.G., Barbash, J.E., Crawford, C.G., Hamilton, P.A., Martin, J.D., Nakagaki, N., Nowell, L.H., Scott, J.C., Stackelberg, P.E., Thelin, G.P., and Wolock, D.M., 2006, The quality of our Nation's waters-Pesticides in the Nation's streams and ground water: 1992-2001: U.S. Geological Survey Circular 1291, 172 p. (Also available at http://pubs.er.usgs.gov/publication/cir1291.)

Google Earth, Inc., 2011, 28¹4'51.11" N 81 39' 25.06" W, Imagery Date, December 2, 2010, accessed July 15, 2012.

Graham, W., and Alva, A., 1998, Ridge citrus water-quality project, Annual Progress Report (1997-1998), University of Florida Institute of Food and Agricultural Sciences, Gainesville, Fla., and Citrus Research Institute, Lake Alfred, Florida. (in Parsons and Boman, 2006).

Jackson, L.D., Alva, A.K., Tucker, D.P.H., and Calvert, 1995, Factors to consider in developing a nutrition program, p.3-11, in Tucker, D.P.H., Alva, A.K., Jackson, L.K., and Wheaton, T.A., eds. Nutrition of Florida citrus trees, Univ. of Florida, SP 169 (see also Obreza and Morgan, 2008, 2nd Edition of this publication).

Lapham, W.W., Wilde, F.D., and Koterba, M.T., 1995, Groundwater data-collection protocols and procedures of the National Water-Quality Assessment Program: Selection, installation, and documentation of wells, and collection of related data: U.S. Geological Survey Open-File Report 95-398, 69 p. 
McMahon, P.B., and Chapelle, F.H., 2008, Redox processes and water quality of selected principal aquifer systems: Ground Water, v. 46, no. 2, p. 259-271.

National Academy of Sciences, 2010, Strategic Planning for the Florida Citrus Industry: Addressing Citrus Greening Disease: Washington, D.C., National Academies Press, 4 p.

National Agricultural Statististics Service, 2006, Agricultural chemical usage, 2005 Fruits summary: U.S. Department of Agriculture [variously paged]. (Also available at http://quickstats.nass.usda.gov, or http://www.nass.usda.gov/Statistics_by_Subject/Environmental/index.asp.)

National Agricultural Statististics Service, 2010, Agricultural chemcial usage, 2009 Fruits summary: U.S. Department of Agriculture [variously paged]. (Also available at http://quickstats.nass.usda.gov, or http://www.nass.usda.gov/Statistics_by_Subject/Environmental/index.asp.)

National Atmospheric Deposition Program, 2012, National Trends Network, accessed March 14, 2012, at http://nadp.sws.uiuc.edu/ntn/.

National Oceanic and Atmospheric Administration, 2010, 1932-2010 Climatological data: Annual summaries for Florida database, accessed August 13, 2012, at $h t t p: / / c d o$. ncdc.noaa.gov/ancsum/ACS.

Obreza, T.A., and Morgan, K.T., eds., 2008, Nutrition of Florida citrus trees: Univ. of Florida, SL 253, 100 p., at http://edis.ifas.ufl.edu/ss478.

Ouellette, D.P., Hansard, Paul, and DeHaven, Eric, 1998, Ground-water quality and agricultural land use in the Polk County Very Intense Study Area (VISA): Florida Department of Environmental Protection, Ambient Program Newsletter, v. 2, no. 2, p. 1-6, and database for AMR 1998-2, accessed March 4, 2012, at http://www.dep.state.fl.us/water/ monitoring/docs/facts/fs9802.pdf.

Page, M., and Stepp, J., 2003, The analysis of organic acids and acid esters in drinking water by liquid chromatography/ mass spectrometry: Florida Department of Agriculture and Consumer Services, Pesticides Laboratory, 12 p.

Parsons, Larry, and Boman, Brian, 2006, Best management practices for Florida citrus: HortTechnology, v. 16, no. 3, p. 389-393.

Rogers, M.E., 2011, Asian citrus psyllid management in Florida: Past, present, and future: Gainesville, Univeristy of Florida, Institute of Food and Agricultural Sciences, Florida Pesticide Review Council Meeting, May 2011, accessed August 13, 2012 at http://www.flaes.org/pesticide/pesticidereviewcouncil.html and slide presentation at http://www.flaes.org/pdf/PRC_2011_Presentations.pdf.
Rogers, M.E., Stansly, P.A., and Stelinski, L.L., 2010, Citrus health management areas (CHMA's): Developing a psyllid management plan: Gainesville, University of Florida, Institute of Food and Agricultural Sciences Extension Publication, accessed August 13, 2012, at http://www. crec.ifas.ufl.edu/extension/chmas/PDF/CHMA_spray\%20 plan_10_11_10.pdf and http://www.crec.ifas.ufl.edu/extension/chmas/index.shtml.

Rogers, M.E., Stansly, P.A., and Stelinski, L.L., 2012, 2012 Florida citrus pest management guide: Asian citrus psyllid and citrus leafminer: Gainesville, University of Florida, Institute of Food and Agricultural Sciences Report SP-43,Document ENY-734, 9 p. (Also available at http://edis.ifas.ufl.edu/pdffiles/IN/IN68600.pdf.)

Rygiel, T., 2001, The analysis of organophosphorous and organonitrogen pesticides in water, soil/sediment, and vegetation by gas chromatography with nitrogen-phosphorous detector (GCNPD): Florida Department of Agriculture and Consumer Services, Pesticides Laboratory, Tallahassee, Fla., $12 \mathrm{p}$.

Rygiel, T., 2003, The analysis of N-methylcarbamoyloximes and $\mathrm{N}$-methyl-carbamates in water by direct aqueous injection HPLC with post column derivatization: Florida Department of Agriculture and Consumer Services, Pesticides Laboratory, Tallahassee, Fla.,13 p.

Sacks, L.A., Swancar, Amy, and Lee, T.M., 1998, Estimating ground-water exchange with lakes using water-budget and chemical mass-balance approaches for ten lakes in Ridge areas of Polk and Highlands Counties, Florida: US Geological Survey Water-Resources Investigations Report 98-4133, $52 \mathrm{p}$.

SAS Institute, Inc., 2008, The Statistical Analysis System (SAS) for Microsoft windows, Version 9.1: Cary, N.C., SAS Institute, Inc., (software), available at http://support.sas.com/onlinedoc/913/docMainpage.jsp.

Silvanima, Jay, Hansard, Paul, and Ouellette, David, [n.d.], Florida Ground Water Quality Monitoring Network: Summary 1994-1997: Florida Department of Environmental Protection database, accessed February 14, 2012, at http:// waterwebprod.dep.state.fl.us/ambient/triennial/default.htm.

Southwest Florida Water Management District, 2009, Standard operating procedures for the collection of water quality and biological samples, revision 8.0: Resource Data and Restoration Department, Water Quality Monitoring Program, $150 \mathrm{p}$.

Southwest Florida Water Management District, 2011, Quality manual for the Southwest Florida Water Management District, revision 19: Brooksville, Fla., Resource Data and Restoration Chemistry Laboratory Section, 115 p. 
Southwest Florida Water Management District, 2012, Water Management Information System (WMIS)- Data Warehouse, available at $h t t p: / / w w w 18 . s w f w m d . s t a t e . f l . u s /$ ResData/Search/ExtDefault.aspx.

Spechler, R.M., and Kroening, S.E., 2007, Hydrology of Polk County, Florida: U.S. Geological Survey Scientific Investigations Report 2006-5320, 114 p. (Also available at http:// pubs.er.usgs.gov/publication/sir20065320.)

Spechler, R.M., 2010, Hydrology and groundwater quality of Highlands County, Florida: U.S. Geological Survey Scientific Investigations Report 2010-5097, 84 p. (Also available at http://pubs.er.usgs.gov/publication/ sir20105097.)

State of Florida, 1994 [amended 1995], Restrictions on the use of bromacil in citrus: Florida Administrative Code, Rule 5E-2.038, accessed August 13, 2012, at http://www.flaes.org/statutesandrules.html, and https://www.flrules.org/gateway/RuleNo.asp?title $=$ PESTICIDES\&ID=5E-2.038.

State of Florida, 1997 [revised 2002 and 2006], Florida aldicarb rule: Florida Administrative Code, Rule 5E-2.028, accessed August 13, 2012, at http://www.flaes.org/statutesandrules.html.

State of Florida, 2002, Nitrogen best management practices (BMPs) for Florida ridge citrus: Florida Statute Title XXXV, Chapter 576.045(6)(a)2, Rule 5E-1.023, accessed August 13, 2012, at http://www.flaes.org/statutesandrules. html.

State of Florida, 2005, Contaminant cleanup target levels, table 1: Groundwater and surface water cleanup target levels: Florida Administrative Code, Rule 62-777, accessed December 1, 2010, at http://www.dep.state.fl.us/waste/ quick_topics/rules/.

State of Florida, 2012, Florida drinking-water standards, monitoring, and reporting: Florida Administrative Code, Rule 62-550, accessed July 1, 2012, at http://www.dep.state. flus/legal/Rules/drinkingwater/62-550.pdf.

Stauffer, R.E., 1991, Effects of citrus agriculture on Ridge lakes in central Florida: Water, Air, and Soil Pollution, v. 59, p. 125-144.

Toccalino, P.L., 2007, Development and application of health-based screening levels for use in water-quality assessments: U.S. Geological Survey Scientific Investigations Report 2007-5106, 12 p. (Also available at http://pubs.usgs.gov/sir/2007/5106/pdf/sir20075106.pdf; additional look-up search table accessed February 16, 2012, at $h t t p: / /$ infotrek.er.usgs.gov/apex/f? $p=169: 1: 0: \because N O \because \cdots$
University of Florida, 2005, Technical report: Development of cleanup target levels (CTLs) for Chapter 62-777, Florida Administrative Code: Gainesville, University of Florida, Center for Environmental and Human Toxicology, 310 p. [Also available at http://www.dep.state.fl.us/waste/quick_ topics/publications/wc/FinalGuidanceDocumentsFlowCharts_April2005/TechnicalReport2FinalFeb2005 (Final3-28-05).pdf

Upchurch, S.B., 1998, Quality of water in Florida's aquifer systems, in Maddox, G.L., Lloyd, J.M., Scott, T.M., Upchurch, S.B., and Copeland, Rick, 1998, Florida's groundwater monitoring program: Background hydrogeochemistry: Tallahassee, Florida Geological Survey Special Publication no. 34, chap. IV, p. 12-51.

U.S. Environmental Protection Agency, 2009, U.S. Environmental Protection Agency: Drinking-water contaminant candidate list 3-Final: Federal Register, v. 74, no. 194, p. $51850-51862$.

U.S. Environmental Protection Agency, 2010, Agreement to terminate all uses of aldicarb: U.S. Environmental Protection Agency, Office of Pesticide Programs, Aldicarb Fact Sheet, accessed March 31, 2011, at http://www.epa.gov/ oppsrrd1/REDs/factsheets/aldicarb_fs.html, accessed $3 / 31 / 2011$.

U.S. Environmental Protection Agency, 2011, The 2011 edition of the drinking-water standards and health advisories: Report EPA 820-R-11-002, Washington, D.C., U.S. Environmental Protection Agency, Office of Water, 18 p. (Also available at $h t t p: / / w a t e r . e p a . g o v / a c t i o n /$ advisories/drinking/upload/dwstandards2011.pdf.

Wheaton, T.A., and Graham, Wendy, 2000, Spatial and temporal distribution of groundwater nitrate in relation to citrus production in central Florida: Final report submitted to Florida Department of Agriculture and Consumer Services, Contract No. 3674, December 2000, 34 p. and appendixes.

Wilson, C., Boman, B., and Hebb, J., 2002, Environmentalconcerns-pesticides, in Boman, B., ed., 2002, Water and Florida Citrus: Gainesville, University of Florida, Institute of Food and Agricultural Sciences, chap. 6, p. 51-66.

Yobbi, D.K., 1996, Analysis and simulation of ground-water flow in Lake Wales Ridge and adjacent areas of Florida: U.S. Geological Survey Water-Resources Investigations Report 94-4254, 82 p. (Also available at http://pubs.er.usgs.gov/publication/wri944254.) 



\section{Prepared by}

U.S. Geological Survey

Science Publishing Network

Raleigh Publishing Service Center

3916 Sunset Ridge Road

Raleigh, NC 27607

A PDF version of this publication is available online at http://pubs.usgs.gov/of/2012/1231/ 
